\title{
Review \\ Immunoregulatory Intestinal Microbiota and COVID-19 in Patients with Type Two Diabetes: A Double-Edged Sword
}

\author{
Pavlo Petakh ${ }^{1,2}{ }^{\oplus}$, Iryna Kamyshna ${ }^{3}{ }^{\circledR}$, Andriy Nykyforuk ${ }^{1}{ }^{\circledR}$, Rouan Yao ${ }^{4}$, John F. Imbery ${ }^{5}$, \\ Valentyn Oksenych ${ }^{5, *}$, Mykhaylo Korda ${ }^{6}$ and Aleksandr Kamyshnyi ${ }^{2, *} \mathbb{C}$
}

1 Department of Biochemistry and Pharmacology, Uzhhorod National University, 88000 Uzhhorod, Ukraine; pavlo.petakh@uzhnu.edu.ua (P.P.); djsunray@gmail.com (A.N.)

2 Department of Microbiology, Virology, and Immunology, I. Horbachevsky Ternopil National Medical University, 46001 Ternopil, Ukraine

3 Department of Medical Rehabilitation, I. Horbachevsky Ternopil National Medical University, Majdan Voli 1, 46001 Ternopil, Ukraine; kamyshna_ii@tdmu.edu.ua

4 Center of Molecular Inflammation Research, Department of Clinical and Molecular Medicine, Norwegian University of Science and Technology, 7491 Trondheim, Norway; rouan.yao@ntnu.no

5 Institute of Clinical Medicine, University of Oslo, 0318 Oslo, Norway; j.f.imbery@medisin.uio.no

6 Department of Medical Biochemistry, I. Horbachevsky Ternopil National Medical University, 46001 Ternopil, Ukraine; kordamm@yahoo.com

* Correspondence: valentyn.oksenych@medisin.uio.no (V.O.); kamyshnyi_om@tdmu.edu.ua or alexkamyshnyi@gmail.com (A.K.)

check for

updates

Citation: Petakh, P.; Kamyshna, I.; Nykyforuk, A.; Yao, R.; Imbery, J.F.; Oksenych, V.; Korda, M.; Kamyshnyi, A. Immunoregulatory Intestinal Microbiota and COVID-19 in Patients with Type Two Diabetes: A

Double-Edged Sword. Viruses 2022, 14, 477. https://doi.org/10.3390/ v14030477

Academic Editor: Ester Ballana Guix

Received: 26 December 2021

Accepted: 24 February 2022

Published: 25 February 2022

Publisher's Note: MDPI stays neutral with regard to jurisdictional claims in published maps and institutional affiliations.

Copyright: (C) 2022 by the authors. Licensee MDPI, Basel, Switzerland. This article is an open access article distributed under the terms and conditions of the Creative Commons Attribution (CC BY) license (https:/ / creativecommons.org/licenses/by/ $4.0 /)$.

\begin{abstract}
Coronavirus disease 2019, or COVID-19, is a major challenge facing scientists worldwide. Alongside the lungs, the system of organs comprising the GI tract is commonly targeted by COVID-19. The dysbiotic modulations in the intestine influence the disease severity, potentially due to the ability of the intestinal microbiota to modulate $\mathrm{T}$ lymphocyte functions, i.e., to suppress or activate $\mathrm{T}$ cell subpopulations. The interplay between the lungs and intestinal microbiota is named the gut-lung axis. One of the most usual comorbidities in COVID-19 patients is type 2 diabetes, which induces changes in intestinal microbiota, resulting in a pro-inflammatory immune response, and consequently, a more severe course of COVID-19. However, changes in the microbiota in this comorbid pathology remain unclear. Metformin is used as a medication to treat type 2 diabetes. The use of the type 2 diabetes drug metformin is a promising treatment for this comorbidity because, in addition to its hypoglycemic action, it can increase amount of intestinal bacteria that induce regulatory $\mathrm{T}$ cell response. This dual activity of metformin can reduce lung damage and improve the course of the COVID-19 disease.
\end{abstract}

Keywords: type 2 diabetes; metformin; COVID-19; SARS-CoV-2; intestinal microbiota; immunoregulation

\section{Introduction}

The human gastrointestinal (GI) tract is represented by an extremely diverse and complex microbial ecosystem with more than $10^{14}$ resident species interacting with the host and actively participating in many physiological processes. Such physiological processes include energy homeostasis, regulation of metabolism, synthesis of vitamins or other important molecules, immune responses, and finally metabolism of xenobiotics, toxins, carcinogens, and other harmful compounds [1-5]. It was found that changes in the intestinal microbiota are connected with various noncommunicable diseases-for example, type 2 diabetes (T2D), cardiovascular disease, GI diseases, and obesity [6-10].

The GI tract is an important target organ for the SARS-CoV-2 virus and possibly affects the severity of COVID-19 disease. GI symptoms, such as nausea, vomiting, and diarrhea, are common in COVID-19 patients. In addition, it was found that the SARS-CoV-2 virus penetrates the cell by binding its S-protein to the human angiotensin-converting enzyme 2 (ACE2) receptor, which, in particular, is widely expressed by intestinal enterocytes [11-13]. 
Evidence suggests diabetes mellitus is one of the most common comorbidities in COVID-19 patients, and pre-existing diabetes mellitus is considered as a risk factor for severe COVID-19 [14]. However, the underlying connection between the two is not fully established. Proinflammatory status, impaired innate immune response, increased ACE2 expression, vascular dysfunction, and prothrombotic status in patients with diabetes are potential contributors of increased vulnerability to SARS-CoV-2 infection and worsening prognostic outcome [15]. The composition of the microbiota in type 2 diabetes (T2D) patients varies, affecting the clinical course of COVID-19 [16]. In this review, we summarize various studies exploring mechanisms of T-lymphocyte modulation by the intestinal microbiota, the role of the gut-lung axis in COVID-19, and changes in the microbiota in T2D and COVID-19.

\section{Immunoregulation, Gut Microbiota, and COVID-19}

\subsection{The Role of Intestinal Microbiota in T-lymphocyte Modulation}

The first lines of defense against SARS-CoV-2 lie within the mucosa-associated lymphoid tissue (MALT) — namely, the nasal-associated lymphoid tissue (NALT) and the gutassociated lymphoid tissue (GALT), which are involved in inducing immune responses towards microorganisms. This is accomplished by promoting the differentiation and activation of immune cells, such as T helper 1 (Th1), Th2, dendritic cells (DCs), and macrophages [17]. Most of the CD4+ T cells are effector or memory T cells located in the intestinal lamina propria [18]. Upon activation by microbiota, antigens are presented by antigen-presenting cells (APCs), such as DCs, causing CD4+ T cells to differentiate into regulatory T cells (Tregs), Th1 cells, Th2, $\mathrm{T}_{\mathrm{FH}}$, and Th17 cells $[19,20]$.

Th1 cells are characterized by expression of the transcription factor T-bet, signal transducer and activator of transcription (STAT) 4 , and the production of IL-2, IFN- $\gamma$, and tumor necrosis factor (TNF) $\beta$. They are involved in the cellular immunity and rejection process. In contrast, Th2 cells, which are mediators of humoral immunity, develop into IL-4-, IL-5-, and IL-13-producing cells by the transcription factor GATA-3 and STAT6. A new lineage of Th cells that selectively produce IL-17 has been proposed. This population, termed Th17, plays a critical role in the induction of inflammation and the pathogenesis of autoimmune diseases and rejection. Th17 cells are characterized by unique signaling pathways triggered by receptor-related orphan receptor (ROR) C2 or ROR- $\alpha$. Th17 cells are involved in the host defense against bacteria, fungi, and viruses [21,22]. Th1, Th2, and Th17 cells are regulated by CD4 + CD25+ Tregs, which are important for the maintenance of peripheral tolerance $[23,24]$. Th17 cells and Tregs are extensively studied subsets of T cells, constituting a large proportion of the effector cells. The imbalance between the cells of these two subsets results in various disorders, ranging from inflammatory and autoimmune diseases to cancer [25].

Active viral replication was found in enterocytes of the small intestine [12]. Although the pathomechanism of GI lesions in SARS-CoV-2 infection was not fully studied, the authors did observe some integral loss of the intestinal barrier and dysbiosis in the microbiota. Violations of the integrity of the intestinal barrier activate the nonspecific and adaptive immune responses, which release pro-inflammatory cytokines into the circulatory system [26].

Dysbiosis can be defined as a reduction in microbial diversity and a combination of (1) the loss of beneficial bacteria, such as Bacteroides strains and butyrate-producing bacteria such as Firmicutes and (2) a rise in pathobionts (symbiotic bacteria that become pathogenic under certain conditions), including Gram-negative Escherichia coli of the phylum Proteobacteria [27]. Furthermore, dysbiosis can prompt multiple immune disorders mediated by $\mathrm{T}$ cells [28]. The $\mathrm{T}$ cell functions are dysregulated in many patients with severe COVID-19 [29,30]. Qin et al. showed that severely affected patients have fewer Tregs (specifically, induced Tregs) [31]. Several studies have also shown that GI tract dysbiosis can alter the Treg/CD4+ T cell axis, and this may result in a pathogenic outcome [32] Secondly, T cells are exhausted in severe COVID-19 patients versus non-severe COVID-19 
patients $[29,30]$. Thus, $\mathrm{T}$ cell exhaustion in severely affected patients may be a combinatorial effect of hyper-inflammation and imbalanced GI microbiota.

Among the vast number of commensal bacteria inhabiting the GI tract, some species of key immunoregulatory bacteria play an important role in controlling the maturation of various T-lymphocyte subpopulations. T-cell receptors (TCRs) of these cells, in turn, are commensal-specific [33]. One of the main functions of the intestinal microbiota is to modulate T-lymphocytes in the GALT. This modulation is carried out in two primary ways, either by individual microorganisms or a consortium of microorganisms working together or by special microbial metabolites. In the following sections, we focus on these two mechanisms in more detail.

\subsubsection{Induction of T-Regulatory Cells (Treg) by Microorganisms and Their Consortia}

Treg cells are important for maintaining immune homeostasis by suppressing an excessive immune response. Two main groups of Tregs have been identified: natural Tregs (nTregs) and peripherally induced Tregs (pTregs). Several consortia of Clostridia species have been identified as potent intestinal Treg inducers [34,35] (Figure 1). For example, colonization by altered Schaedler flora (ASF), which includes Lactobacillus acidophilus, Lactobacillus murinus, Bacteroides distasonis, Mucispirillum schaedleri, Eubacterium plexicaudatum, a fusiform-shaped bacterium (ASF 356), and two Clostridium species (ASF 356, ASF 502) all induce expansion of Tregs [36].

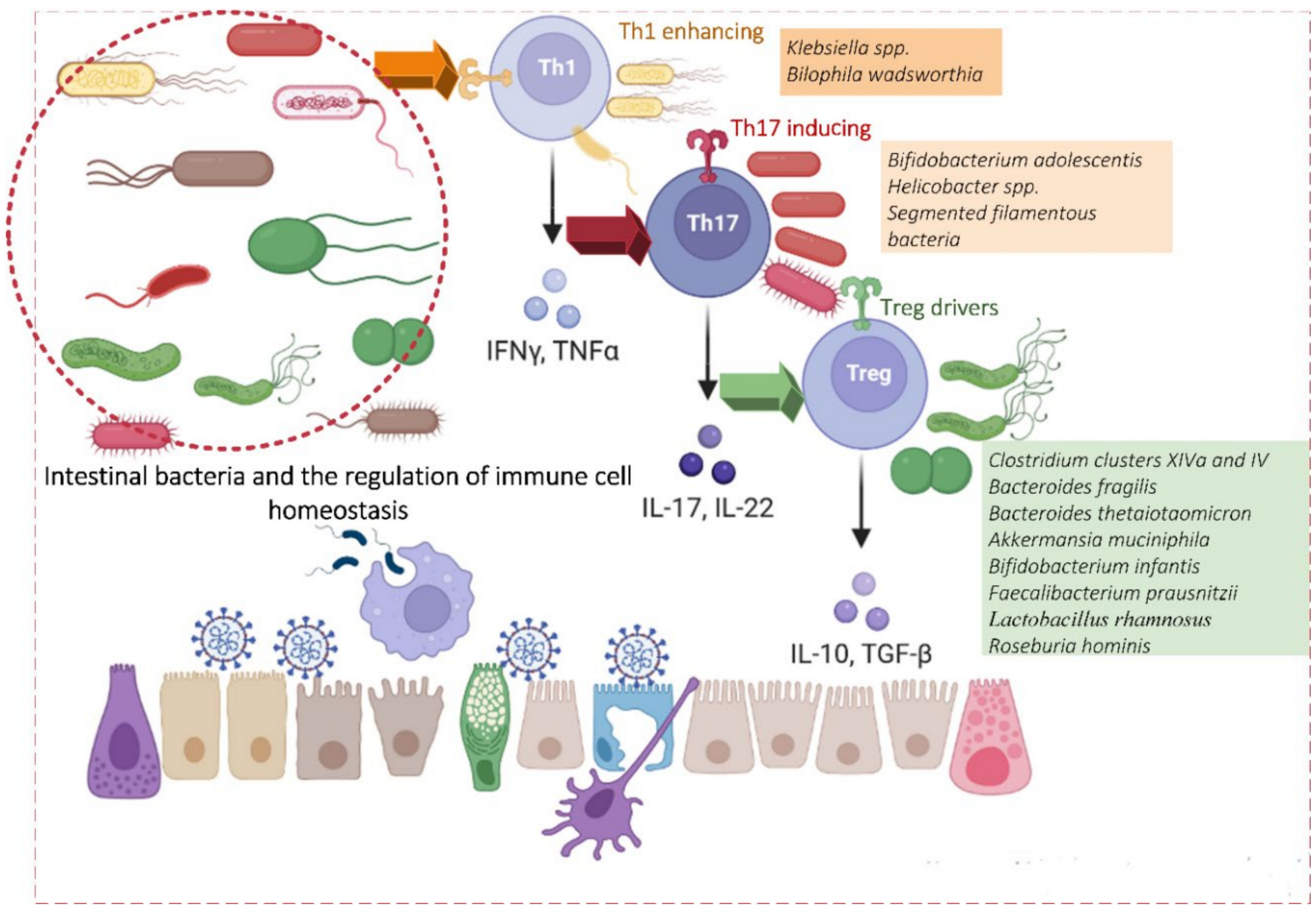

Figure 1. Intestinal bacteria and immune cell homeostasis regulation. The main bacterial inducers of intestinal CD4+ T cells are shown.

Clostridial cluster IV and XIVa co-induce transforming growth factor-beta (TGF $\beta$ ) secretion by epithelial cells in the intestine, resulting in pTreg differentiation and proliferation in the large intestine [35,37]. Recently, intestinal induction of pTreg after colonization by an inherently more complex mouse microbiota, Oligo-MM12, has also been described [38]. Oligo-Mouse-Microbiota (Oligo-MM12), a community of 12 strains representing members of the major bacterial phyla in the murine gut, is another microbial composition that is 
proving useful in evaluating how the microbiota influences disease development and therapeutics [39].

Among the 19 clusters (I to XIX) of the class Clostridia living in the intestine, the representatives of clusters IV and XIVa, known as Clostridium leptum and Clostridium coccoides, respectively, have the greatest potential of inducing Tregs [35]. Clostridium cluster XIVa includes species belonging to the Clostridium, Ruminococcus, Eubacterium, Coprococcus, Roseburia, Lachnospira, Dorea, and Butyrivibrio genera. Clostridium cluster IV is composed of the Clostridium, Ruminococcus, Anaerofilum, and Eubacterium genera [40]. Treg-inducing activity was detected in mice following colonization by a 46-strain cocktail of the genus Clostridium [35]. Additionally, a cocktail of 17 human strains of Clostridia that induced Treg activity has also been identified and described [34].

Species Faecalibacterium prausnitzii (one of the representatives of Clostridium cluster IV) affects the balance of Th17/Treg in the GALT [41]. Th17/Treg balance is important for maintaining immune homeostasis, as Th17s cause autoimmunity and inflammation, while conversely, Tregs suppress these pathological processes [42]. F. prausnitzii is one of the key butyrate producers in the intestine and can decrease inflammation by stimulating the production of IL-10 and blocking activation of nuclear factor NF-KB [43]. This leads to inhibition of pro-inflammatory cytokines (IFN- $\gamma$, TNF- $\alpha$, IL $-1 \beta$, IL-8, IL-12) and increased activity of Foxp3+ Tregs in the GALT [43]. In 2016, a protein called microbial antiinflammatory molecule (MAM) was identified in F. prausnitzii culture supernatants [44]. At least seven peptides of the protein MAM induced in vitro production of IL-10 and blocked the development of DSS-induced colitis in mice in vivo [45].

Representatives of the phylum Bacteroidetes, Bacteroides fragilis and Bacteroides thetaiotaomicron, are also inducers of Treg differentiation in the gut [46]. Important metabolites of B. fragilis are short-chain fatty acids (SCFAs), which act as a link between the microflora and immune system by activating GALT cells through free fatty acid receptors (FFARs) [47].

Bacteroides thetaiotaomicron and Clostridium ramosum, which were studied by Sefik et al. [48], are two individual bacterial species capable of inducing $\operatorname{ROR} \gamma+$ Treg activation. $\operatorname{ROR} \gamma+$ Tregs constitute the main subgroup of Tregs in the colon and differentiate in response to bacterial antigens 15-20 days after birth [47]. Mice with $\operatorname{ROR} \gamma+$ Treg deficiency demonstrate microbial dysbiosis, an increase in inflammatory Th17 cells, and are more susceptible to colitis in various models [49-51].

\subsubsection{Induction of Th1 Cells by Microorganisms and Their Consortia}

So far, only a very limited number of commensal species have been described that stimulate a non-inflammatory homeostatic Th1 response. One study identified Klebsiella, which is typically present in the oral cavity but can ectopically colonize the gut under conditions of dysbiosis and induce a strong Th1 response [52]. This response was proinflammatory and dependent on CD11b-CD103+ expression [53].

\subsubsection{Induction of Th17 Cells by Microorganisms and Their Consortia}

Segmented filamentous bacteria (SFB) are one of the main inducers of Th17 cells. Mice without SFB showed reduced levels of Th17 when compared with genetically identical mice colonized by a microbiota containing these bacteria [54]. Th17s express a surface TCR specific for SFB antigens. Epithelial adhesion of SFB stimulates the production of reactive oxygen species (ROS) and serum amyloid A (SAA), which play a significant role in the differentiation of Th17 cells [55]. Thus, epithelial adhesion of SFB induces activation of SFB-specific Th17 cells.

Why does SFB mainly induce Th17 cell differentiation? A key feature of SFB is a close association with epithelial cells in the intestine. Atarashi and colleagues, by using mousespecific strains of SFB, found that only strains derived from the original host were able to cause induction of Th17 cells due to species-specific adhesion [56]. SFB adhesion induced the expression of serum amyloid proteins SAA1/2 and reactive protein dual oxidase 2 (Duox2), resulting in reactive oxygen species (ROS) production in epithelial cells. SAA1 
enhances the induction of IL-17A and IL-17F expression by Th17 cells and also affects DCs by promoting Th17 activation and enhancing ROR $\gamma \mathrm{t}+$ expression. In addition, the action of IL-22, a canonical cytokine of Th17s, is increased and effectively upregulates antimicrobial peptides. Upregulation of antimicrobial peptides causes the appearance or disappearance of bacteria such as C. rodentium and some pathogenic strains of $S$. typhimurium, E. coli, and Yersinia enterocolitica [54]. Colonization of SFB enhances the expression of MHC class II on intestinal epithelial cells and affects enterocyte glycosylation. These changes in glycosylation often result in expression of glycolipids GM1 (GM1 gangliosidosis), purported to inhibit the attachment of another adherent microbe [57,58]. According to new data, SFB has also been identified in humans $[59,60]$. Symbiotic bacteria Bifidobacterium adolescentis induce a strong population of Th17 cells in the gut without provoking inflammation of the mucous membrane [61].

\subsubsection{Induction of $\mathrm{T}$ Follicular Helper $\left(\mathrm{T}_{\mathrm{FH}}\right)$ Cells by Microorganisms and Their Consortia}

In Peyer's patches (PPs), $\mathrm{T}_{\mathrm{FH}}$ cells support $\mathrm{B}$ cell maturation in germinal centers and their differentiation into plasma IgA-secreting cells [62]. Extracellular ATP produced by microbes regulates $\mathrm{T}_{\mathrm{FH}}$ cell activation, which in turn controls the level of secretory IgA [63]. A. muciniphila has been shown to induce antigen-specific $\mathrm{T}_{\mathrm{FH}}$ cells to stimulate antigen-specific, T-dependent production of IgA and $\mathrm{IgG}_{1}$ [64]. SFB induced PPs $\mathrm{T}_{\mathrm{FH}}$ cell differentiation by inhibiting the IL-2 signaling pathway in PPs. Despite recent attention on the $\mathrm{T}_{\mathrm{FH}}$ cell field, little is known regarding the interaction of commensals and $\mathrm{T}_{\mathrm{FH}}$ cells [65].

\subsubsection{Induction of $\mathrm{T}$ lymphocytes by Microbial Metabolites Short-Chain Fatty Acids}

Three major SCFAs produced by gut bacteria are acetate, propionate, and butyrate [66]. These are aliphatic carboxylic acids containing 1 carbon in the carboxylic function and 1,2 , and 3 carbons in the aliphatic tail, respectively [66]. Several groups of bacteria can produce acetate, including those belonging to clusters IV and XIVa Clostridia species, and are also an important source of butyrate in the intestine [67]. Propionate is formed by the bacterial species Bacteroides and Firmicutes [67]. Butyrate and acetate have been shown to promote induction and function of intestinal Tregs by several mechanisms-e.g., by enhancing Foxp3 expression in CD4 T cells via increased histone acetylation [68]. The effects of SCFAs are mediated by binding to FFARs, such as G protein-coupled receptors (GPCRs) expressed on CD4+ T cells (GPR43, also known as FFAR2) and DCs (GPR109A) [69]. Unlike SCFAs, long-chain fatty acids enhance the differentiation and proliferation of Th1 and Th17 cells [70] (Figure 2).

\section{Adenosine Triphosphate (ATP)}

Luminal ATP has been shown to promote differentiation of intestinal Th17 cells and can be obtained from both the host and the microbiota [47]. ATP derived from commensal bacteria can activate a subset of lamina propria cells, $\mathrm{CD} 70^{\text {high }} \mathrm{CD} 11 \mathrm{c}$ low , leading to the differentiation of Th17 cells [71]. Systemic or rectal administration of ATP into germfree mice results in a marked increase in the number of lamina propria Th17 cells. A $\mathrm{CD} 70^{\text {high }} \mathrm{CD} 11 c^{\text {low }}$ subset of the lamina propria cells express IL-6, IL-23p19, and TGF- $\beta$ activating integrin- $\alpha \mathrm{V}$ and $-\beta 8$, in response to ATP stimulation, preferentially inducing Th17 differentiation. The critical role of ATP is further underscored by the observation that administration of ATP exacerbates a T-cell-mediated colitis model with enhanced Th17 differentiation [72].

\section{Microbial Polysaccharides}

A good example of a bacterial compound with immunomodulatory activity is polysaccharide A (PSA), produced by B. fragilis [73]. PSA was reported to prevent colitis in mice [74]. This protective effect of PSA (via B. fragilis) was mediated by production of IL-10 from the intestinal Tregs in a TLR2-dependent mechanism [75], as well as by indirect 
effects on conventional [76] or plasmacytoid DCs [77]. In addition, B. fragilis has been shown to release PSA through outer membrane vesicles (OMVs) transported to DCs [76,78]. These OMV-primed DCs protected animals from experimental colitis through induction of intestinal Tregs.

Mannan/ $\beta$-1,6-glucan-containing polysaccharides (MGCP) are capable of exerting potent anti-inflammatory effects on the immune system. MGCP facilitates Treg induction from naive T cells through a unique Dectin1-Cox2 signaling axis in DCs. Furthermore, through a TLR2-dependent mechanism, it restrains Th1 differentiation of effector T cells by suppressing IFN- $\gamma$ expression [79].

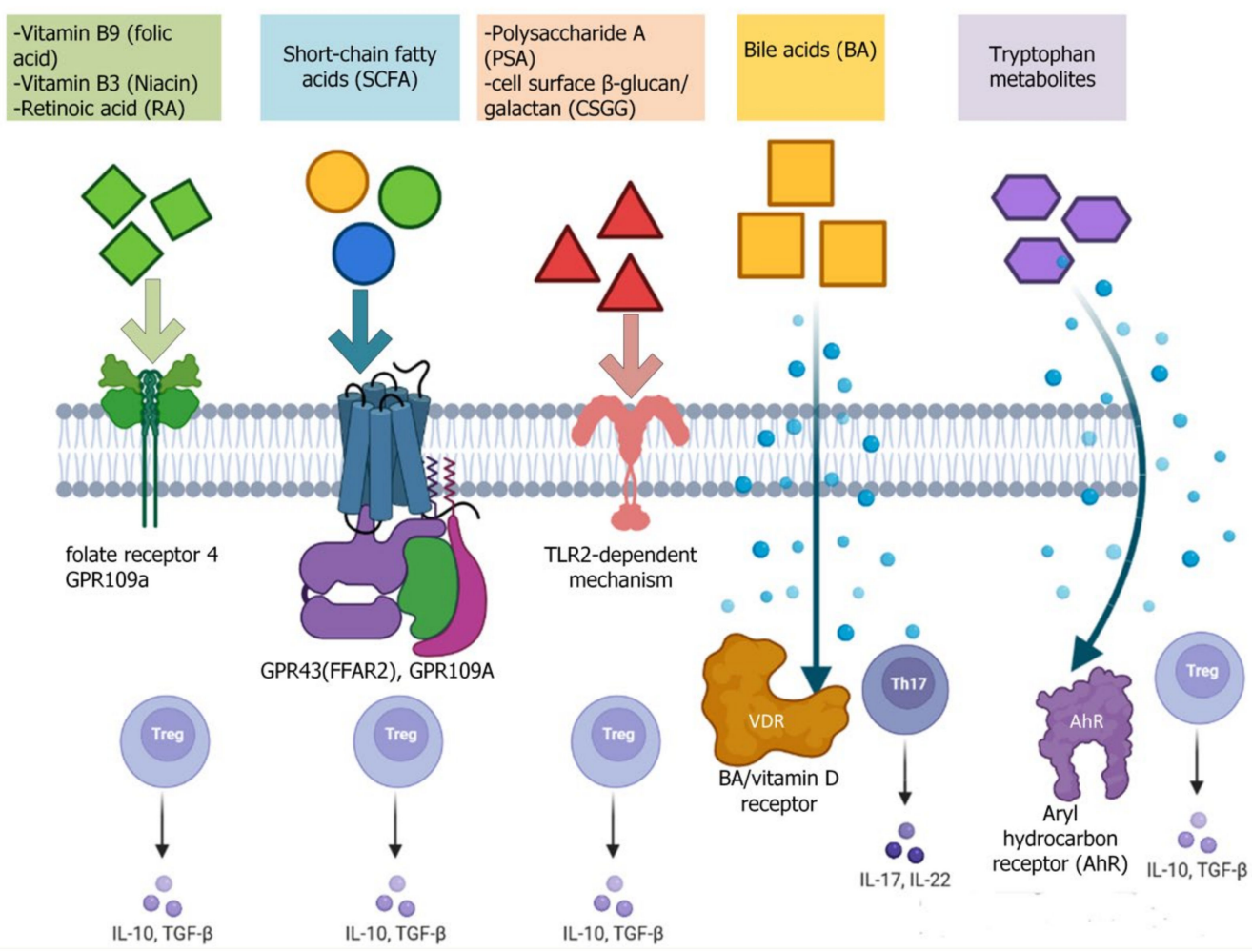

Figure 2. Induction of T-lymphocytes by microbial metabolites. Shown here are the main mechanisms of intestinal CD4+ T cell induction by major microbial metabolites.

\section{Vitamins}

Retinoic acid (a metabolite of vitamin A1) promotes Treg induction and inhibits the development of Th17 cells [80]. Folate receptor 4, a vitamin B9 receptor, is highly expressed on the surfaces of Treg cells, implying a specific role for this vitamin in regulation of Treg cell function [81]. In the absence of folic acid (vitamin B9), naive T cells can differentiate into Tregs. However, these differentiated Treg cells fail to survive due to a concomitant decrease in expression of anti-apoptotic molecules (e.g., Bcl-2). As a result, mice maintained on a vitamin B9-deficient diet have decreased numbers of intestinal Treg cells. Consequently, the impaired survival of Treg cells in these mice leads to their increased susceptibility to intestinal inflammation [82]. Niacin (vitamin B3) signals through the G-protein-coupled receptor (GPR) 109a. This interaction induces anti-inflammatory properties, including the expression of retinal dehydrogenases in colon macrophages and DCs, which in turn trigger Treg differentiation. GPR109a-deficient mice contain reduced colonic Tregs and heightened susceptibility to colonic inflammation [83]. Thus, vitamin B3 promotes colonic Treg generation and maintains colon homeostasis [84]. 
Bile Acids

Bile acids (BAs) function as signaling molecules with pleiotropic metabolic and immune effects through interaction with host receptors and the microbiota. Primary BAs are synthesized from cholesterol in the liver and conjugated to either taurine or glycine prior to secretion into bile. After a meal, BAs are expelled into the small intestine to facilitate fat absorption. BAs are efficiently maintained within the enterohepatic circulation by ileal and hepatic transporter systems. However, $5 \%$ to $10 \%$ of BAs that are not reabsorbed can serve as substrates for microbial metabolism and undergo biotransformation to secondary BAs. The major biotransformations include hydrolysis of conjugated BAs to free BAs and glycine or taurine by bile salt hydrolase (BSH); $7 \alpha$-dehydroxylation of cholic acid (CA) and chenodeoxycholic acid (CDCA), yielding deoxycholic acid (DCA) and lithocholic acid (LCA), respectively; and BA $7 \beta$-dehydroxylation of ursodeoxycholic acid (UDCA), yielding LCA [85-87].

Mice fed a high-fat diet showed altered conjugated BA composition, leading to increases in the sulfate-reducing bacterium Bilophila wadsworthia. These changes were associated with enhanced intestinal Th1 responses and the development of colitis in genetically susceptible IL-10-deficient animals [88]. The BA metabolite isoallolithocholic acid enhances the differentiation of anti-inflammatory Treg cells by facilitating the formation of a permissive chromatin structure in the promoter region of the transcription factor Foxp3 [89].

\subsection{The Role of Intestinal Microbes in Pulmonary Diseases, Gut-Lung Axis, and Changes in Intestinal Microbiota in COVID-19 Patients}

Research by Xu et al. demonstrated patients with COVID-19 had a reduction in genera such as Bifidobacterium and Lactobacillus [90]. In another study, Zuo et al. examined the intestinal microbiota of 15 patients with SARS-CoV-2 infection by collecting fecal samples 2-3 times during their hospital stay [91]. They found a decreased number of commensal bacteria (Eubacterium ventriosum, Faecalibacterium prausnitzii, Roseburia, and Lachnospiraceae) and an increased amount of opportunistic pathogens (Clostridium hathewayi, Actinomyces viscosus, and Bacteroides nordii). Microorganisms such as Coprobacillus, Clostridium hathewayi, and Clostridium ramosum have also been linked to disease severity [92] (Table 1). The same authors found that COVID-19 patients had significantly reduced microbial diversity, more opportunistic bacteria (i.e., Streptococcus, Rothia, Veillonella, Actinomyces), and a reduction in the number of beneficial symbionts. Yeoh et al. utilized DNA sequencing to analyze the intestinal microbiota of 100 hospitalized patients with COVID-19 (34 received antibiotics, 73 received antivirals) and found that intestinal dysbiosis was connected with disease severity in patients receiving antibiotics [93]. Additionally, in patients with COVID-19 disease, there was a significant reduction in the number of Actinobacterium, Bifidobacterium adolescentis, Faecalibacterium prausnitzii, and Eubacterium rectale in comparison with healthy controls [93]. A number of these bacteria also correlated with the severity of COVID-19 [93].

$\mathrm{Lv}$ et al. studied the connection between changes in the intestinal microbiota and clinical signs of COVID-19 in 67 hospitalized COVID-19 patients. Here, the authors found a significant reduction in the number of fungi Chromista, Mucoromycota, Ascomycota, and Basidiomycota compared with uninfected people. Mucoromycota positively correlates with microorganisms, such as Intestinibater, Peptostreptococcaceae, Aspergillus, Agathobacter, and Fusicatenibacter.

Also noteworthy are the studies of Tang et al., which examined the intestinal microbiota of 57 COVID-19 patients and stratified results depending on disease severity. In patients with mild COVID-19, a negative correlation of C-reactive protein (CRP) with C. butyricum was observed. In the severe group, C. leptum and F. prausnitzii positively correlated with the concentration of neutrophils, and E. rectale positively correlated with the IL-6 concentration. In patients with a critical course of COVID-19, levels of $C$. butyricum negatively correlated with the concentration of CRP, and Bifidobacterium negatively correlated with prothrombin time and LDH [94]. 
Table 1. COVID-19 and gut microbiota changes.

\begin{tabular}{|c|c|c|c|c|}
\hline Research & Study Design & Number of Participants & Research Methods & Microbiota Changes \\
\hline $\begin{array}{c}\text { Zuo et al. } \\
\text { [91] }\end{array}$ & $\begin{array}{l}\text { Single-center, } \\
\text { prospective }\end{array}$ & $\begin{array}{l}15 \text { COVID-19 patients } \\
\text { compared against } \\
6 \text { subjects with } \\
\text { community-acquired } \\
\text { pneumonia and } \\
15 \text { healthy individuals }\end{array}$ & $\begin{array}{l}\text { Metagenomic } \\
\text { sequencing }\end{array}$ & $\begin{array}{c}\text { Significant changes in the microbiota } \\
\text { of the GI tract (dysbiosis) in patients } \\
\text { with COVID-19. Positive correlation } \\
\text { between the severity of COVID-19 } \\
\text { and dysbiosis. }\end{array}$ \\
\hline $\begin{array}{c}\text { Gu et al. } \\
\text { [92] }\end{array}$ & $\begin{array}{l}\text { Single-center, } \\
\text { cross-sectional }\end{array}$ & $\begin{array}{l}30 \text { COVID-19 patients } \\
\text { compared against } 24 \mathrm{H} 1 \mathrm{~N} 1 \\
\text { patients and } 30 \text { matched } \\
\text { healthy controls }\end{array}$ & 16S rRNA sequencing & $\begin{array}{l}\text { Significantly reduced diversity of } \\
\text { bacteria (dysbiosis), significantly } \\
\text { lower relative number of beneficial } \\
\text { symbionts, and higher relative } \\
\text { number of opportunistic pathogens } \\
\text { in COVID-19. }\end{array}$ \\
\hline $\begin{array}{l}\text { Yeoh et al. } \\
\text { [93] }\end{array}$ & $\begin{array}{l}\text { Prospective cohort } \\
\text { study from } \\
\text { two centers }\end{array}$ & $\begin{array}{c}100 \text { COVID-19 patients } \\
\text { compared against matched } \\
\text { healthy controls }\end{array}$ & $\begin{array}{c}\text { Sequencing of fecal } \\
\text { DNA. Assessment } \\
\text { of levels of } \\
\text { inflammatory markers. }\end{array}$ & $\begin{array}{l}\text { Significant changes in the microbiota } \\
\text { of the GI tract (dysbiosis) in } \\
\text { COVID-19 patients. Dysbiosis } \\
\text { continued even after } 30 \text { days } \\
\text { post-illness. Significant correlation } \\
\text { of dysbiosis with COVID-19 severity } \\
\text { and numerous pro-inflammatory } \\
\text { markers in serum. }\end{array}$ \\
\hline
\end{tabular}

Abnormal signs of microorganisms were observed in plasma samples from approximately $65 \%$ of

$\begin{array}{cccc}\text { Prasad } & \begin{array}{c}\text { Prospective cohort } \\ \text { study from }\end{array} & \begin{array}{c}30 \text { hospitalized patients } \\ \text { with COVID-19 and }\end{array} & \begin{array}{c}\text { 16S rRNA sequencing } \\ \text { and markers of }\end{array} \\ \text { et al. [95] } & \text { one center } & 16 \text { healthy subjects. } & \text { intestinal permeability }\end{array}$

COVID-19 patients. Compared with the uninfected control group, plasma levels of intestinal permeability markers (such as FABP2, PGN, and LPS) were significantly higher in COVID-19 patients.

\begin{tabular}{|c|c|c|c|c|}
\hline $\begin{array}{l}\text { Newsome } \\
\text { et al. [96] }\end{array}$ & $\begin{array}{l}\text { Prospective cohort } \\
\text { study from } \\
\text { one center }\end{array}$ & $\begin{array}{l}50 \text { hospitalized } \\
\text { COVID-19 patients, } \\
9 \text { recovered patients, and } \\
34 \text { uninfected subjects. }\end{array}$ & 16S rRNA sequencing & $\begin{array}{l}\text { The microbial composition of feces } \\
\text { differed significantly in COVID-19 } \\
\text { patients. Patients with COVID-19 } \\
\text { had an increased relative amount of } \\
\text { Campylobacter and Klebsiella spp. }\end{array}$ \\
\hline $\begin{array}{l}\text { Lv et al. } \\
\text { [97] }\end{array}$ & $\begin{array}{l}\text { Prospective cohort } \\
\text { study from } \\
\text { one center }\end{array}$ & $\begin{array}{l}56 \text { hospitalized } \\
\text { COVID-19 patients and } \\
47 \text { healthy subjects. }\end{array}$ & $\begin{array}{l}\text { Metabolomics, gas } \\
\text { chromatography }\end{array}$ & $\begin{array}{l}\text { There were differences in the } \\
\text { metabolomes of COVID-19 patients } \\
\text { compared with uninfected members } \\
\text { of the control group. }\end{array}$ \\
\hline $\begin{array}{l}\text { Tanget } \\
\text { et al. [94] }\end{array}$ & Cohort study & $\begin{array}{c}\text { Total: } 57 \\
\text { (20 mild hospitalized } \\
\text { COVID-19 patients, } \\
19 \text { severe hospitalized } \\
\text { COVID-19 patients, } \\
18 \text { critical hospitalized } \\
\text { COVID-19 patients) }\end{array}$ & qPCR & $\begin{array}{l}\text { Intestinal dysbiosis progressed } \\
\text { depending on the severity of the } \\
\text { disease. Significant reduction in } \\
\text { the number of probiotic bacteria } \\
\text { Bifidobacterium and Lactobacillus } \\
\text { compared with uninfected people. } \\
\text { Significant decrease in the number } \\
\text { of butyrate-producing bacteria } \\
\text { (anti-inflammatory bacteria) } \\
\text { C. leptum, F. prausnitzii, E. rectale, } \\
\text { and C. butyricum compared with } \\
\text { uninfected people. }\end{array}$ \\
\hline
\end{tabular}


Table 1. Cont.

\begin{tabular}{|c|c|c|c|c|}
\hline Research & Study Design & Number of Participants & Research Methods & Microbiota Changes \\
\hline $\begin{array}{l}\text { Chen et al. } \\
\text { [98] }\end{array}$ & Cohort study & $\begin{array}{l}30 \text { hospitalized } \\
\text { COVID-19 patients }\end{array}$ & 16S rRNA sequencing & $\begin{array}{l}\text { At the beginning of the disease, } \\
\text { dysbiosis was observed, and it } \\
\text { continued throughout } \\
\text { the disease course. } \\
\text { A correlation was found between } \\
\text { the severity of the disease course } \\
\text { and the diversity of } \\
\text { the intestinal microbiota. }\end{array}$ \\
\hline $\begin{array}{l}\text { Mazzarelliet } \\
\text { et al. [99] }\end{array}$ & Cohort study & $\begin{array}{c}\text { Total: } 23 \\
\text { (6 COVID-19 patients in } \\
\text { the ICU (i-COVID-19); } \\
\text { 9 COVID-19 patients in the } \\
\text { infectious disease wards } \\
\text { (w-COVID-19), } \\
3 \text { non-COVID-19 } \\
\text { hospitalized patients } \\
\text { in the ICU, } \\
5 \text { non-COVID-19 patients } \\
\text { in general ward) }\end{array}$ & qPCR & $\begin{array}{l}\text { Decreased microbial diversity in } \\
\text { ICU-treated COVID-19 patients } \\
\text { compared with those treated in the } \\
\text { infectious department. Significant } \\
\text { increase in opportunistic pathogens } \\
\text { Enterobacteriaceae, Actinobacteria, } \\
\text { Proteobacteria, Peptostreptococcaceae, } \\
\text { Staphylococcaceae, Aerococcaceae, } \\
\text { Vibrionaceae, and Dermabacteraceae } \\
\text { compared with patients without } \\
\text { COVID-19. Significant reduction } \\
\text { in fusobacteria and spirochetes } \\
\text { compared with patients } \\
\text { without COVID-19. }\end{array}$ \\
\hline
\end{tabular}

Aspergillus niger was common in

COVID-19 patients and positively correlated with symptoms of

Total: 150

(67 hospitalized

COVID-19 patients, 35 hospitalized

H1N1 patients, 48 healthy individuals)
qPCR with primers ITS1f and ITS2r

diarrhea. Significant reduction in the number of Mucoromycota,

Basidiomycota, Ascomycota, and Chromista, compared with

uninfected people. Mucoromycota positively correlates with opportunistic pathogens Intestinibater, Agathobacter,

Peptostreptococcaceae, Aspergillus, and Fusicatenibacter. Penicillium citrinum was negatively correlated with the concentration of CRP.

Intestinal dysbiosis may be an important factor in severe

COVID-19 infection. Significant increase in Kluyneromyces,

$\begin{array}{ccc}\text { Yu et al. } & \text { Cohort study } & \text { Total: } 3 \text { hospitalized } \\ \text { [101] } & \text { COVID-19 patients } & \text { Sequencing }\end{array}$

Aspergillus, Firmicutes, Actinobacteria, and Corynebacterium in

COVID-19 patients compared with uninfected subjects.

It has been established that intestinal microbiota affects lung status through crossinteraction via the gut-lung axis [102] (Figure 3). The gut-lung axis is bidirectional, meaning that microbial metabolites and endotoxins can affect the lungs, and simultaneously, lung tissue inflammation can affect the intestinal microbiota [103]. This idea is, to some extent, consistent with studies researching intestinal dysbiosis in COVID-19. 
Acute Respiratory Distress Syndrome (ARDS) Alveolar Changes

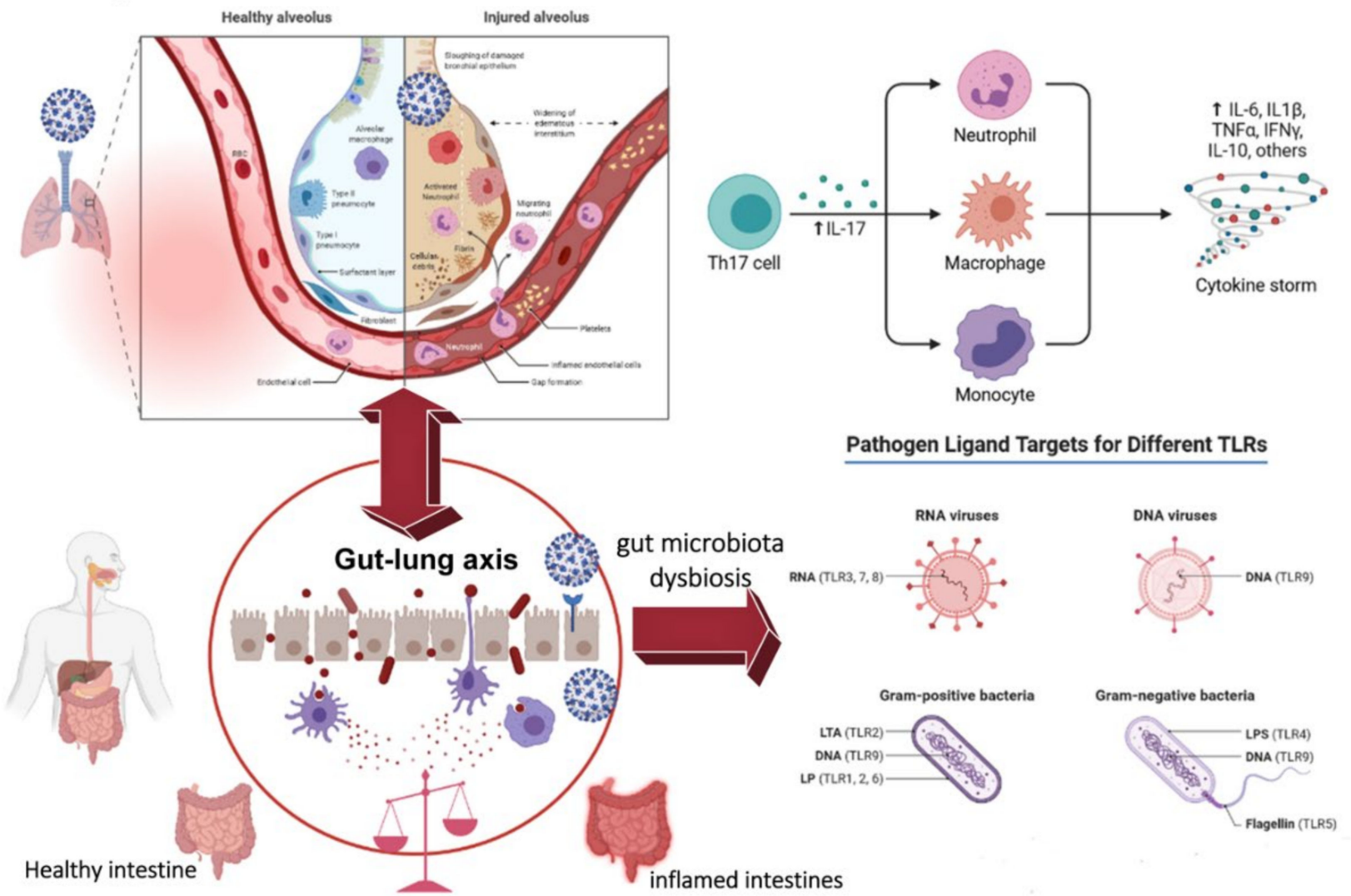

Figure 3. The gut-lung axis in COVID-19.

An example of microbiota influence on the gut-lung axis is seen when SFB in the gut stimulates the lung Th17 response, protecting it from Streptococcus pneumoniae infection and enhancing lung mucosal immunity [104]. Dysbiosis of intestinal flora has been associated with respiratory diseases such as asthma and cystic fibrosis $[105,106]$. One study showed endogenous Bifidobacteria spp. intestinal flora caused by a fatal influenza infection can enhance resistance to the virus [107]. Conversely, lung inflammation can affect intestinal flora. For example, influenza virus infection in mice can increase the number of Enterobacteriaceae and reduce the number of Lactobacillus spp. and Lactococcus spp. in the gut [103,108-111]. Another example is that after lipopolysaccharide (LPS) administration to mice, the resultant dysbiosis of the lung microbiota will be accompanied by disturbance of the intestinal flora as bacteria moves from the lungs into the bloodstream [103,108-111]. These studies have shown that microbes play an essential role in the cross-talk between the gut and the lungs and that microbial dysbiosis in the lungs may affect gut homeostasis and vice versa [111].

The gut-lung axis is the link between the intestinal microbiota and the lungs. Dysbiosis can affect inflammation of lung tissue due to inhibition of anti-inflammatory Tregs and induction of pro-inflammatory Th17s by bacterial metabolites. The result is a cytokine storm, which is a severe complication of COVID-19.

\subsection{The Role of Intestinal Microbiota in Type 2 Diabetes Mellitus}

The intestinal microbiota is connected to the pathogenesis of numerous chronic illnesses, including T2D. Changes in the intestinal microbiota composition in T2D are shown in Table 2. 
Table 2. Type 2 diabetes and gut microbiota changes.

\begin{tabular}{|c|c|c|c|c|c|}
\hline \multirow{2}{*}{ Research } & \multirow{2}{*}{ Study Design } & \multirow{2}{*}{ Number of Participants } & \multirow{2}{*}{$\begin{array}{l}\text { Research } \\
\text { Methods }\end{array}$} & \multicolumn{2}{|c|}{ Changes in the Intestinal Microbiota } \\
\hline & & & & Increase & Decrease \\
\hline $\begin{array}{l}\text { Candela et al. } \\
\text { [112] }\end{array}$ & Open-label trial & $\begin{array}{l}40 \text { patients with T2D } \\
\text { and } 13 \text { healthy controls }\end{array}$ & $\begin{array}{c}16 S \text { rRNA } \\
\text { sequencing }\end{array}$ & $\begin{array}{c}\text { Enterobacteriaceae, } \\
\text { Collinsella, } \\
\text { Streptococcus, } \\
\text { Lactobacillus }\end{array}$ & $\begin{array}{c}\text { Bacteroides, } \\
\text { Lachnospira, } \\
\text { Prevotella, } \\
\text { Roseburia, } \\
\text { Faecalibacterium }\end{array}$ \\
\hline $\begin{array}{l}\text { Sedighi et al. } \\
\text { [113] }\end{array}$ & Case-control study & $\begin{array}{l}18 \text { patients with T2D } \\
\text { and } 18 \text { healthy controls }\end{array}$ & $\begin{array}{l}16 \mathrm{~S} \text { rRNA } \\
\text { sequencing }\end{array}$ & Lactobacillus & Bifidobacterium \\
\hline $\begin{array}{c}\text { Wu et al. } \\
\text { [114] }\end{array}$ & Double-blind study & $\begin{array}{l}16 \text { patients with T2D } \\
\text { and } 12 \text { healthy controls }\end{array}$ & $\begin{array}{c}\text { 16S rRNA } \\
\text { sequencing }\end{array}$ & No data & $\begin{array}{l}\text { B. vulgatus and } \\
\text { Bifidobacterium }\end{array}$ \\
\hline $\begin{array}{l}\text { Larsen et al. } \\
\text { [115] }\end{array}$ & Open-label trial & $\begin{array}{l}18 \text { patients with T2D } \\
\text { and } 18 \text { healthy controls }\end{array}$ & $\begin{array}{c}16 S \text { rRNA } \\
\text { sequencing }\end{array}$ & $\begin{array}{l}\text { Bacteroidetes, } \\
\text { C. coccoides, } \\
\text { Firmicutes }\end{array}$ & $\begin{array}{l}\text { Clostridia, } \\
\text { Firmicutes }\end{array}$ \\
\hline
\end{tabular}

The most common microorganisms with potential antidiabetic effects are Bacteroides and Bifidobacterium spp. Bifidobacterium is considered by most studies an antidiabetic microorganism [112,113,116,117]. The antidiabetic properties of Bifidobacterium infantis, Bifidobacterium pseudocatenulatum, Bifidobacterium bifidum, Bifidobacterium animalis, Bifidobacterium longum, and Bifidobacterium breve have also been demonstrated by improved glucose tolerance in various animal models [118-121]. Similar properties were observed for the genus Bacteroides-namely, Bacteroides acidifaciens [122] and Bacteroides uniformis [123]. Akkermansia muciniphila is another protective organism against the development of diabetes. A negative correlation was shown between increasing amounts of this bacterium and the course of T2D [124,125].

The study by Eckburg et al. demonstrated that the intestinal microbiota of people with T2D was characterized by an increase in Bacteroides spp., E. coli, and Desulfovibrio spp. [126]. Conversely, healthy controls demonstrated an increase in butyrate-producing bacteria-namely, Clostridium spp., Eubacterium rectale, and F. prausnitzii [126].

In comparison with their healthy counterpart, Kim-Anne Lê et al. found a reduction in the number of Bifidobacteria alongside an increased amount of Enterococcus in the intestines of T2D patients [127].

Decreased butyrate levels lead to reduced pancreatic secretion, resulting in lowered levels of glucagon, insulin, and insulin sensitivity [128]. Furthermore, elevated acetic acid levels can activate the parasympathetic nervous system, stimulating the islets of Langerhans beta cells to secrete more insulin, increasing food intake and the development of T2D diabetes [129].

\subsection{Changes in the Gut Microbiota in Patients with Type 2 Diabetes Receiving Metformin}

With the recent development of next-generation (high-throughput, deep) sequencing (NGS) technology, more research has begun focusing on metformin effects on the intestinal microbiota. Table 3 summarizes ten studies on metformin effects on the intestinal microbiota in obese or T2D patients, two of which were performed in obese patients $[130,131]$ and eight in patients with T2D [132-139]. 
Table 3. Gut microbiota in patients with T2D receiving metformin.

\begin{tabular}{|c|c|c|c|c|c|c|}
\hline \multirow[b]{2}{*}{ Research } & \multirow[b]{2}{*}{$\begin{array}{l}\text { Research } \\
\text { Methods }\end{array}$} & \multicolumn{2}{|c|}{ Number of Participants } & \multirow[b]{2}{*}{$\begin{array}{l}\text { Dosage of } \\
\text { Metformin }\end{array}$} & \multicolumn{2}{|c|}{ Changes in the Intestinal Microbiota } \\
\hline & & $\begin{array}{l}\text { Metformin- } \\
\text { untreated } \\
\text { T2D }\end{array}$ & $\begin{array}{l}\text { Metformin- } \\
\text { treated }\end{array}$ & & Increase & Decrease \\
\hline $\begin{array}{l}\text { Forslund et al. } \\
\text { [132] }\end{array}$ & Metagenomics & 106 & 93 & No data & Escherichia & No data \\
\hline $\begin{array}{l}\text { Cuesta- } \\
\text { Zuluaga et al. } \\
\text { [133] }\end{array}$ & 16sRNA & 14 & 14 & No data & $\begin{array}{c}\text { Prevotella, } \\
\text { Megasphaera, Butyrivibrio }\end{array}$ & $\begin{array}{l}\text { Oscillospira, } \\
\text { Barnesiellaceae }\end{array}$ \\
\hline $\begin{array}{l}\text { Wu et al. } \\
\text { [117] }\end{array}$ & Metagenomics & 22 & 22 & $1700 \mathrm{mg} / \mathrm{d}$ & $\begin{array}{c}\text { Pectobacterium, Pantoea, } \\
\text { Serratia, Raphidiopsis, } \\
\text { Dickeya, Helicobacter, } \\
\text { Bacillus, Rheinheimera, } \\
\text { Citrobacter, Yersinia, } \\
\text { Shewanella, Enterobacter, } \\
\text { Erwinia, Cronobacter, } \\
\text { Dermacoccus, } \\
\text { Pseudomonas, Salmonella, } \\
\text { Klebsiella, Escherichia }\end{array}$ & $\begin{array}{c}\text { Pseudogulbenkiania, } \\
\text { Subdoligranulum, } \\
\text { Acetivibrio, Bartonella, } \\
\text { Dethiosulfovibrio, } \\
\text { Hippea, } \\
\text { Pseudoflavonifractor, } \\
\text { Deferribacter, } \\
\text { Intestinibacter }\end{array}$ \\
\hline $\begin{array}{l}\text { Hung et al. } \\
\text { [135] }\end{array}$ & qPCR & 23 & 23 & No data & Enterobacteriaceae & No data \\
\hline $\begin{array}{l}\text { Sun et al. } \\
\text { [134] }\end{array}$ & Metagenomics & 22 & 22 & $1000 \mathrm{mg} / \mathrm{d}$ & No data & Bacteroides fragilis \\
\hline $\begin{array}{l}\text { Barengolts } \\
\text { et al. [136] }\end{array}$ & 16sRNA & 11 & 21 & No data & $\begin{array}{l}\text { Bifidobacterium, } \\
\text { Catenibacterium, } \\
\text { Parabacteroides }\end{array}$ & No data \\
\hline $\begin{array}{c}\text { Ejtahed et al. } \\
\text { [131] }\end{array}$ & 16sRNA & 20 & 20 & $1000 \mathrm{mg} / \mathrm{d}$ & Escherichia/Shigella & No data \\
\hline $\begin{array}{l}\text { Zhang et al. } \\
\text { [137] }\end{array}$ & 16sRNA & 26 & 51 & No data & $\begin{array}{l}\text { Actinobacteria, } \\
\text { Fusobacteria, } \\
\text { Betaproteobacteria }\end{array}$ & $\begin{array}{c}\text { Gammaproteobacteria, } \\
\text { Erysipelotrichi }\end{array}$ \\
\hline $\begin{array}{l}\text { Hiel et al. } \\
\text { [130] }\end{array}$ & 16sRNA & 53 & 42 & No data & $\begin{array}{c}\text { Akkermansia, Clostridium } \\
\text { cluster XIVa, Clostridium } \\
\text { cluster XIVb, Klebsiella, } \\
\text { Escherichia/Shigella }\end{array}$ & $\begin{array}{c}\text { Roseburia, Clostridium } \\
\text { cluster XI, Clostridium } \\
\text { cluster XVIII }\end{array}$ \\
\hline $\begin{array}{c}\text { Chavez- } \\
\text { Carbajal et al. } \\
{[138]}\end{array}$ & 16sRNA & 14 & 14 & No data & $\begin{array}{l}\text { Bacteroidales, } \\
\text { Acidobacteriales, } \\
\text { Pelomonas spp. }\end{array}$ & No data \\
\hline
\end{tabular}

Summarizing and comparing the results in rodent models and human patients, metformin significantly increased the number of bacteria from phylum Verrucomicrobianamely, Akkermansia muciniphila [140]. This bacteria is the only species of the phylum Verrucomicrobia present in humans [140]. Akkermansia muciniphila is one of the well-known utilizers of mucin, which is decreased in patients with diabetes, obesity, and cardiovascular disease not treated with metformin. It plays a vital role in maintaining intestinal mucosa integrity, reducing the migration of pro-inflammatory LPS, and improving blood glucose levels [141-144]. Another clinical study of 27 healthy young adults (the participants were given metformin up to $1 \mathrm{~g}$ twice daily) found that metformin reduced Clostridium spp. and Intestinibacter spp., while the number of Escherichia/Shigella spp. and Bilophila wadsworthia increased [145]. The main mechanisms of metformin's effect on the intestinal microbiota are summarized below. 


\subsubsection{Maintaining the Integrity of the Intestinal Barrier}

The interaction between the intestinal barrier integrity and the gut microbiota is very important in the development and progression of metabolic diseases. Shin et al. found an increased level of LPS induced by a high-fat diet in serum is inhibited by metformin and suggested this was due to the changes in the intestinal microbiota composition [146]. Similarly, metformin protected intestinal barrier function and reduced blood LPS levels in a mouse model of insulin resistance and obesity [147]. In addition, exogenous administration of LPS blocked the enhancement of blood glucose control and insulin signaling caused by metformin. These results indicate that metformin might improve glucose metabolism by maintaining intestinal barrier function [148].

\subsubsection{Enhancement of SCFAs Synthesis}

SCFAs produced by the gut microbiota can exert beneficial effects on peripheral tissues, such as adipose tissue, skeletal muscle, and liver, by controlling substrate metabolism and function to improve insulin sensitivity. The ability of the gut microbiota to produce butyrate and propionate is enhanced in patients treated with metformin. Metformin treatment may result in an increased number of SCFA-producing bacteria, such as Akkermansia, Butyricicoccus, Ruminococcus, Phascolarctobacterium, Coprococcus, Allobaculum, Bacteroides, Blautia, Lactobacillus, and Butyricimonas [149,150]. Metformin has also been shown to enhance active and total glucagon-like peptide 1, which is consistent with the hypothesis that it increases SCFA production through modification of the gut microbiota composition [151,152].

\subsubsection{Regulation of Bile Acid Metabolism}

Improving glucose metabolism with metformin treatment was shown by its ability to regulate the total serum BAs of diabetic rats. Wu et al. showed a significant increase in plasma BAs during 4-month metformin treatment, while BAs in fecal samples remained unchanged. The level of BSH produced by the intestinal microbiota increased in the second month of metformin treatment [117]. Sun et al. analyzed the gut microbiota in patients newly diagnosed with T2D who were treated for the first time with a 3-day metformin regimen. They found metformin increased the level of glycoursodeoxycholic acid by regulating the gut microbiota (such as inhibition of Bacteroides fragilis growth) [134]. In turn, regulation of the gut microbiota inhibited the farnesoid $X$ receptor signaling pathway to reduce blood glucose and maintain blood glucose homeostasis [134]. Finally, it was found that metformin reduced the reabsorption of BA in the distal ileum, leading to increased bile salt concentration within the colon [153]. Herein lies a potential explanation for the effects of metformin on the colonic microbiota [153].

\subsection{Discussion and Conclusions}

The intestinal microbiota is a complex consortium of microorganisms affecting most systems of the human body. Undoubtedly, one of the most important tasks of the intestinal microbiota is the modulation of immune cells. Representatives of the intestinal microbiota can activate different subpopulations of $\mathrm{T}$ lymphocytes in the intestinal plate, both directly and indirectly through metabolites, which may ultimately lead to enhancement and suppression of certain T lymphocyte subpopulations.

COVID-19 has become a major challenge for society and science. The emerging data suggest that immune system dysregulation could be a link connecting COVID-19 infection severity, diabetes, and the microbiota [154]. Researchers found not only a link between the influence of the intestinal microbiota on the immune system, but also a direct effect on the lungs, which was called the gut-lung axis. The mesenteric lymphatic system is an important communication route between the intestine and the lungs. It allows intact bacteria, their fragments, or metabolites to translocate through the intestinal barrier, reach the circulatory system, and modulate the lung's immune response [155]. For example, SCFAs, which are mainly synthesized through the fermentation of bacterial dietary fibers, act as signaling 
molecules in the lungs in cells presenting resident antigens, thereby reducing inflammatory and allergic responses [156,157].

Diabetes and older age are both risk factors for severe disease and increased mortality in patients with COVID-19 [158]. Indeed, the case fatality rate for patients with no comorbidities is approximately $0.9 \%$, but it rises to $7.3 \%$ for those with diabetes [159]. The chronic inflammatory condition in T2D is considered the underlying mechanism for the "cytokine storm" complication and worsens the outcomes of COVID-19 [160]. It is assumed that hyperinflammation may result in multiorgan failure, a general complication in critical COVID-19 cases [161].

In recent years, it has been reported that $\mathrm{T}$ cells play key roles in the progression of T2D. This included T2D association with overactivated T cells and subsequent activation of inflammatory pathways [162]. Additionally important has been an immune response in T2D patients defined by the balance between Treg and Th1 or Th17 cells. Tregs suppress the activities of Th1, Th2, and Th17 cells to improve insulin resistance. Moreover, it has been described that the percentage of Tregs was decreased in peripheral blood of T2D patients, especially in newly diagnosed patients [163-165]. This culminated in inflammation and insulin resistance [163-165]. Similarly, it was reported that both the Treg/Th17 ratio and Treg/Th1 ratio decreased in patients suffering from T2D [166,167]. These intestinal immunomodulatory cells are a peculiar bridge between the intestinal microbiota and diabetes [168].

When compared with healthy controls, T2D patients commonly have a decreased amount of SCFA-producing bacteria (Eubacterium rectale, Faecalibacterium prausnitzii, Roseburia intestinalis, Roseburia inulinivorans, Akkermansia, and Bifidobacterium) and tryptophan metabolite-producing bacteria (Lactobacillus, Bacteroides, Bifidobacterium, Peptostreptococcus, Ruminococcus, Ruminiclostridium, and Clostridium) [124,169-174]. There is also a concurrent increase in the amount of opportunistic pathogens (Bacteroides caccae and Clostridium hathewayi), branch chain amino acid synthesizing bacteria (Bacteroides vulgatus and Prevotella copri), and sulfate-metabolizing bacteria (Desulfovibrio, Lactobacillus gasseri, and Lactobacillus reuteum) compared with healthy controls [124,169-174]. Since SCFAs regulate Th17s/Tregs, the reduction in SCFA-producing bacteria in T2D may be related to COVID-19-induced hyperinflammation through the gut-lung axis [175].

In the review, we document research describing changes to gut microbiota in two important worldwide diseases: COVID-19 and T2D. Nonetheless, the question of how the microbiota changes during comorbidity remains unresolved. In our opinion, dysbiosis in T2D may influence the course of COVID-19 through the gut-lung axis. Decreased number of SCFA-producing bacteria during T2D may regulate the level of Tregs and, consequently, could be a contributing factor in the development of the cytokine storm.

Given the proposed interplay between COVID-19 and T2D, the use of metformin is promising. In addition to its hypoglycemic action, it can affect the intestinal microbiota, leading to increased production of microbial metabolites such as SCFAs that induce Treg cells, which, in turn, modulates excessive immune responses. This property of metformin is not well-publicized and has important therapeutic potential. Metformin also has possible additional antiviral activity against SARS-CoV-2 infection via activation of the protein kinase by AMP (AMPK), leading to the phosphorylation of ACE2 and resulting in conformational and functional changes in the surface protein. This may lead to a subsequent increase in ACE2 expression via AMPK that may lead to a decrease in SARS-CoV-2 binding [176].

Author Contributions: Conceptualization, and writing-original draft preparation, P.P., A.N. and A.K.; writing-review and editing, P.P., V.O., R.Y. and J.F.I.; supervision, A.K. and V.O.; project administration, V.O. and A.K.; visualization, I.K.; funding acquisition, M.K. and V.O. All authors have read and agreed to the published version of the manuscript.

Funding: This research received no external funding.

Institutional Review Board Statement: Not applicable. 


\section{Informed Consent Statement: Not applicable.}

Conflicts of Interest: The authors declare no conflict of interest.

\section{References}

1. Maslowski, K.M.; Mackay, C.R. Diet, gut microbiota and immune responses. Nat. Immunol. 2011, 12, 5-9. [CrossRef] [PubMed]

2. Thaiss, C.A.; Zmora, N.; Levy, M.; Elinav, E. The microbiome and innate immunity. Nature 2016, 535, 65-74. [CrossRef] [PubMed]

3. Blander, J.M.; Longman, R.S.; Iliev, I.D.; Sonnenberg, G.F.; Artis, D. Regulation of inflammation by microbiota interactions with the host. Nat. Immunol. 2017, 18, 851-860. [CrossRef] [PubMed]

4. Gill, S.R.; Pop, M.; DeBoy, R.T.; Eckburg, P.B.; Turnbaugh, P.J.; Samuel, B.S.; Gordon, J.I.; Relman, D.A.; Fraser-Liggett, C.M.; Nelson, K.E. Metagenomic analysis of the human distal gut microbiome. Science 2006, 312, 1355-1359. [CrossRef] [PubMed]

5. Lloyd-Price, J.; Abu-Ali, G.; Huttenhower, C. The healthy human microbiome. Genome Med. 2016, 8, 1-11. [CrossRef]

6. Gurung, M.; Li, Z.; You, H.; Rodrigues, R.; Jump, D.B.; Morgun, A.; Shulzhenko, N. Role of gut microbiota in type 2 diabetes pathophysiology. EBioMedicine 2020, 51, 102590. [CrossRef]

7. Khan, I.; Ullah, N.; Zha, L.; Bai, Y.; Khan, A.; Zhao, T.; Che, T.; Zhang, C. Alteration of gut microbiota in inflammatory bowel disease (IBD): Cause or consequence? IBD treatment targeting the gut microbiome. Pathogens 2019, 8, 126. [CrossRef]

8. Tang, W.W.; Kitai, T.; Hazen, S.L. Gut microbiota in cardiovascular health and disease. Circ. Res. 2017, 120, 1183-1196. [CrossRef]

9. Baumgart, D.C.; Carding, S.R. Inflammatory bowel disease: Cause and immunobiology. Lancet 2007, 369, 1627-1640. [CrossRef]

10. Turnbaugh, P.J.; Ley, R.E.; Mahowald, M.A.; Magrini, V.; Mardis, E.R.; Gordon, J.I. An obesity-associated gut microbiome with increased capacity for energy harvest. Nature 2006, 444, 1027-1031. [CrossRef]

11. Jin, X.; Lian, J.-S.; Hu, J.-H.; Gao, J.; Zheng, L.; Zhang, Y.-M.; Hao, S.-R.; Jia, H.-Y.; Cai, H.; Zhang, X.-L. Epidemiological, clinical and virological characteristics of 74 cases of coronavirus-infected disease 2019 (COVID-19) with gastrointestinal symptoms. Gut 2020, 69, 1002-1009. [CrossRef]

12. Lamers, M.M.; Beumer, J.; van der Vaart, J.; Knoops, K.; Puschhof, J.; Breugem, T.I.; Ravelli, R.B.; Van Schayck, J.P.; Mykytyn, A.Z.; Duimel, H.Q. SARS-CoV-2 productively infects human gut enterocytes. Science 2020, 369, 50-54. [CrossRef] [PubMed]

13. Zang, R.; Castro, M.F.G.; McCune, B.T.; Zeng, Q.; Rothlauf, P.W.; Sonnek, N.M.; Liu, Z.; Brulois, K.F.; Wang, X.; Greenberg, H.B. TMPRSS2 and TMPRSS4 promote SARS-CoV-2 infection of human small intestinal enterocytes. Sci. Immunol. 2020, 5, eabc3582. [CrossRef]

14. Chan, J.C.; Lim, L.-L.; Wareham, N.J.; Shaw, J.E.; Orchard, T.J.; Zhang, P.; Lau, E.S.; Eliasson, B.; Kong, A.P.; Ezzati, M. The Lancet Commission on diabetes: Using data to transform diabetes care and patient lives. Lancet 2020, 396, 2019-2082. [CrossRef]

15. Li, G.; Chen, Z.; Lv, Z.; Li, H.; Chang, D.; Lu, J. Diabetes Mellitus and COVID-19: Associations and Possible Mechanisms. Int. J. Endocrinol. 2021, 2021, 7394378. [CrossRef] [PubMed]

16. Tilg, H.; Moschen, A.R. Microbiota and diabetes: An evolving relationship. Gut 2014, 63, 1513-1521. [CrossRef] [PubMed]

17. Gallo, O.; Locatello, L.G.; Mazzoni, A.; Novelli, L.; Annunziato, F. The central role of the nasal microenvironment in the transmission, modulation, and clinical progression of SARS-CoV-2 infection. Mucosal Immunol. 2021, 14, 305-316. [CrossRef] [PubMed]

18. Wang, L.; Zhu, L.; Qin, S. Gut microbiota modulation on intestinal mucosal adaptive immunity. J. Immunol. Res. 2019, $2019,4735040$. [CrossRef]

19. Feng, T.; Elson, C.O. Adaptive immunity in the host-microbiota dialog. Mucosal Immunol. 2011, 4, 15-21. [CrossRef]

20. Jones, L.; Ho, W.Q.; Ying, S.; Ramakrishna, L.; Srinivasan, K.G.; Yurieva, M.; Ng, W.P.; Subramaniam, S.; Hamadee, N.H.; Joseph, S. A subpopulation of high IL-21-producing CD4+ T cells in Peyer's Patches is induced by the microbiota and regulates germinal centers. Sci. Rep. 2016, 6, 1-17.

21. Peck, A.; Mellins, E.D. Plasticity of T-cell phenotype and function: The T helper type 17 example. Immunology 2010, 129, 147-153. [CrossRef]

22. Crome, S.; Wang, A.; Levings, M.J.C.; Immunology, E. Translational mini-review series on Th17 cells: Function and regulation of human T helper 17 cells in health and disease. Clin. Exp. Immunol. 2010, 159, 109-119. [CrossRef] [PubMed]

23. Sakaguchi, S. Naturally arising Foxp3-expressing CD25+CD4+ regulatory T cells in immunological tolerance to self and non-self. Nat. Immunol. 2005, 6, 345-352. [CrossRef] [PubMed]

24. Akbar, A.N.; Vukmanovic-Stejic, M.; Taams, L.S.; Macallan, D.C. The dynamic co-evolution of memory and regulatory CD4+ T cells in the periphery. Nat. Rev. Immunol. 2007, 7, 231-237. [CrossRef] [PubMed]

25. Sun, L.; Fu, J.; Zhou, Y. Metabolism controls the balance of Th17/T-regulatory cells. Front. Immunol. 2017, 8, 1632. [CrossRef] [PubMed]

26. Golonka, R.M.; Saha, P.; Yeoh, B.S.; Chattopadhyay, S.; Gewirtz, A.T.; Joe, B.; Vijay-Kumar, M. Harnessing Innate Immunity to Eliminate SARS-COV-2 and Ameliorate COVID-19 Disease; American Physiological Society: Bethesda, MD, USA, 2020; Volume 52, pp. 217-221.

27. Humphreys, C. 19-Intestinal Permeability. In Textbook of Natural Medicine, 5th ed.; Pizzorno, J.E., Murray, M.T., Eds.; Churchill Livingstone: St. Louis, MO, USA, 2020; pp. 166-177.e164. [CrossRef]

28. Honda, K.; Littman, D.R. The microbiota in adaptive immune homeostasis and disease. Nature 2016, 535, 75-84. [CrossRef] [PubMed] 
29. Braun, J.; Loyal, L.; Frentsch, M.; Wendisch, D.; Georg, P.; Kurth, F.; Hippenstiel, S.; Dingeldey, M.; Kruse, B.; Fauchere, F. SARS-CoV-2-reactive T cells in healthy donors and patients with COVID-19. Nature 2020, 587, 270-274. [CrossRef] [PubMed]

30. Diao, B.; Wang, C.; Tan, Y.; Chen, X.; Liu, Y.; Ning, L.; Chen, L.; Li, M.; Liu, Y.; Wang, G. Reduction and functional exhaustion of T cells in patients with coronavirus disease 2019 (COVID-19). Front. Immunol. 2020, 11, 827. [CrossRef] [PubMed]

31. Qin, C.; Zhou, L.; Hu, Z.; Zhang, S.; Yang, S.; Tao, Y.; Xie, C.; Ma, K.; Shang, K.; Wang, W. Dysregulation of immune response in patients with coronavirus 2019 (COVID-19) in Wuhan, China. Clin. Infect. Dis. 2020, 71, 762-768. [CrossRef] [PubMed]

32. Pandiyan, P.; Bhaskaran, N.; Zou, M.; Schneider, E.; Jayaraman, S.; Huehn, J. Microbiome dependent regulation of Tregs and Th17 cells in mucosa. Front. Immunol. 2019, 10, 426. [CrossRef] [PubMed]

33. Sorini, C.; Cardoso, R.F.; Gagliani, N.; Villablanca, E.J. Commensal bacteria-specific CD4+ T cell responses in health and disease. Front. Immunol. 2018, 9, 2667. [CrossRef]

34. Atarashi, K.; Tanoue, T.; Oshima, K.; Suda, W.; Nagano, Y.; Nishikawa, H.; Fukuda, S.; Saito, T.; Narushima, S.; Hase, K. T reg induction by a rationally selected mixture of Clostridia strains from the human microbiota. Nature 2013, 500, 232-236. [CrossRef] [PubMed]

35. Atarashi, K.; Tanoue, T.; Shima, T.; Imaoka, A.; Kuwahara, T.; Momose, Y.; Cheng, G.; Yamasaki, S.; Saito, T.; Ohba, Y. Induction of colonic regulatory T cells by indigenous Clostridium species. Science 2011, 331, 337-341. [CrossRef] [PubMed]

36. Geuking, M.B.; Cahenzli, J.; Lawson, M.A.; Ng, D.C.; Slack, E.; Hapfelmeier, S.; McCoy, K.D.; Macpherson, A.J. Intestinal bacterial colonization induces mutualistic regulatory T cell responses. Immunity 2011, 34, 794-806. [CrossRef]

37. Rainey, F.; Tanner, R.; Wiegel, J. Family Clostridiaceae. In The Prokaryotes: A Handbook on the Biology of Bacteria: Bacteria: Firmicutes, Cyanobacteria, 3rd ed.; Springer: New York, NY, USA, 2006; Volume 3, pp. 654-678.

38. Wyss, M.; Brown, K.; Thomson, C.A.; Koegler, M.; Terra, F.; Fan, V.; Ronchi, F.; Bihan, D.; Lewis, I.; Geuking, M.B. Using precisely defined in vivo microbiotas to understand microbial regulation of IgE. Front. Immunol. 2020, 10, 3107. [CrossRef] [PubMed]

39. Gomes-Neto, J.C.; Mantz, S.; Held, K.; Sinha, R.; Munoz, R.R.S.; Schmaltz, R.; Benson, A.K.; Walter, J.; Ramer-Tait, A.E. A real-time PCR assay for accurate quantification of the individual members of the Altered Schaedler Flora microbiota in gnotobiotic mice. J. Microbiol. Methods 2017, 135, 52-62. [CrossRef]

40. Lopetuso, L.R.; Scaldaferri, F.; Petito, V.; Gasbarrini, A. Commensal Clostridia: Leading players in the maintenance of gut homeostasis. Gut Pathog. 2013, 5, 1-8. [CrossRef]

41. Zhou, L.; Zhang, M.; Wang, Y.; Dorfman, R.G.; Liu, H.; Yu, T.; Chen, X.; Tang, D.; Xu, L.; Yin, Y. Faecalibacterium prausnitzii produces butyrate to maintain Th17/Treg balance and to ameliorate colorectal colitis by inhibiting histone deacetylase 1. Inflamm. Bowel Dis. 2018, 24, 1926-1940. [CrossRef]

42. DONG, X.; WU, Y.; ZHANG, J.; CHEN, W.; HUANG, Q.; WEI, W. Effects of IgD on the balance of Th1/Th2 and Th17/Treg subsets and transcription factors expression in human peripheral blood. Chin. J. Clin. Pharmacol. Ther. 2018, 23, 488.

43. Ferreira-Halder, C.V.; de Sousa Faria, A.V.; Andrade, S.S. Action and function of Faecalibacterium prausnitzii in health and disease. Best Pract. Res. Clin. Gastroenterol. 2017, 31, 643-648. [CrossRef]

44. Quévrain, E.; Maubert, M.; Michon, C.; Chain, F.; Marquant, R.; Tailhades, J.; Miquel, S.; Carlier, L.; Bermúdez-Humarán, L.; Pigneur, B. Identification of an anti-inflammatory protein from Faecalibacterium prausnitzii, a commensal bacterium deficient in Crohn's disease. Gut 2016, 65, 415-425. [CrossRef]

45. Breyner, N.M.; Michon, C.; de Sousa, C.S.; Vilas Boas, P.B.; Chain, F.; Azevedo, V.A.; Langella, P.; Chatel, J.M. Microbial antiinflammatory molecule (MAM) from Faecalibacterium prausnitzii shows a protective effect on DNBS and DSS-induced colitis model in mice through inhibition of NF-kB pathway. Front. Microbiol. 2017, 8, 114. [CrossRef] [PubMed]

46. Telesford, K.M.; Yan, W.; Ochoa-Reparaz, J.; Pant, A.; Kircher, C.; Christy, M.A.; Begum-Haque, S.; Kasper, D.L.; Kasper, L.H. A commensal symbiotic factor derived from Bacteroides fragilis promotes human CD39+ Foxp3+ T cells and Treg function. Gut Microbes 2015, 6, 234-242. [CrossRef] [PubMed]

47. Sefik, E.; Geva-Zatorsky, N.; Oh, S.; Konnikova, L.; Zemmour, D.; McGuire, A.M.; Burzyn, D.; Ortiz-Lopez, A.; Lobera, M.; Yang, J. Individual intestinal symbionts induce a distinct population of ROR $\gamma+$ regulatory T cells. Science 2015, 349, 993-997. [CrossRef] [PubMed]

48. Kuczma, M.P.; Szurek, E.A.; Cebula, A.; Chassaing, B.; Jung, Y.-J.; Kang, S.-M.; Fox, J.G.; Stecher, B.; Ignatowicz, L. Commensal epitopes drive differentiation of colonic Tregs. Sci. Adv. 2020, 6, eaaz3186. [CrossRef] [PubMed]

49. Ohnmacht, C.; Park, J.-H.; Cording, S.; Wing, J.B.; Atarashi, K.; Obata, Y.; Gaboriau-Routhiau, V.; Marques, R.; Dulauroy, S.; Fedoseeva, M. The microbiota regulates type 2 immunity through ROR $\gamma t+$ T cells. Science 2015, 349, 989-993. [CrossRef] [PubMed]

50. Xu, M.; Pokrovskii, M.; Ding, Y.; Yi, R.; Au, C.; Galan, C.; Bonneau, R.; Littman, D.R. c-Maf-dependent regulatory T cells mediate immunological tolerance to intestinal microbiota. bioRxiv 2017. [CrossRef]

51. Al Nabhani, Z.; Dulauroy, S.; Marques, R.; Cousu, C.; Al Bounny, S.; Déjardin, F.; Sparwasser, T.; Bérard, M.; Cerf-Bensussan, N.; Eberl, G. A weaning reaction to microbiota is required for resistance to immunopathologies in the adult. Immunity 2019, 50, 1276-1288.e1275. [CrossRef]

52. Atarashi, K.; Suda, W.; Luo, C.; Kawaguchi, T.; Motoo, I.; Narushima, S.; Kiguchi, Y.; Yasuma, K.; Watanabe, E.; Tanoue, T. Ectopic colonization of oral bacteria in the intestine drives TH1 cell induction and inflammation. Science 2017, 358, 359-365. [CrossRef]

53. Tanoue, T.; Morita, S.; Plichta, D.R.; Skelly, A.N.; Suda, W.; Sugiura, Y.; Narushima, S.; Vlamakis, H.; Motoo, I.; Sugita, K. A defined commensal consortium elicits CD8 T cells and anti-cancer immunity. Nature 2019, 565, 600-605. [CrossRef] 
54. Ivanov, I.I.; Atarashi, K.; Manel, N.; Brodie, E.L.; Shima, T.; Karaoz, U.; Wei, D.; Goldfarb, K.C.; Santee, C.A.; Lynch, S.V. Induction of intestinal Th17 cells by segmented filamentous bacteria. Cell 2009, 139, 485-498. [CrossRef] [PubMed]

55. Lee, J.-Y.; Hall, J.A.; Kroehling, L.; Wu, L.; Najar, T.; Nguyen, H.H.; Lin, W.-Y.; Yeung, S.T.; Silva, H.M.; Li, D. Serum amyloid A proteins induce pathogenic Th17 cells and promote inflammatory disease. Cell 2020, 180, 79-91.e16. [CrossRef] [PubMed]

56. Atarashi, K.; Tanoue, T.; Ando, M.; Kamada, N.; Nagano, Y.; Narushima, S.; Suda, W.; Imaoka, A.; Setoyama, H.; Nagamori, T. Th17 cell induction by adhesion of microbes to intestinal epithelial cells. Cell 2015, 163, 367-380. [CrossRef]

57. Zheng, Y.; Valdez, P.A.; Danilenko, D.M.; Hu, Y.; Sa, S.M.; Gong, Q.; Abbas, A.R.; Modrusan, Z.; Ghilardi, N.; De Sauvage, F.J. Interleukin-22 mediates early host defense against attaching and effacing bacterial pathogens. Nat. Med. 2008, 14, 282-289. [CrossRef] [PubMed]

58. Goto, Y.; Umesaki, Y.; Benno, Y.; Kiyono, H. Specific comensal bacteria modulate epithelial glycosylaion (59.5). Am. Assoc. Immnol. 2011, 186, 59.5 .

59. Jonsson, H.; Hugerth, L.W.; Sundh, J.; Lundin, E.; Andersson, A.F. Genome sequence of segmented filamentous bacteria present in the human intestine. Commun. Biol. 2020, 3, 1-9. [CrossRef] [PubMed]

60. Chen, B.; Chen, H.; Shu, X.; Yin, Y.; Li, J.; Qin, J.; Chen, L.; Peng, K.; Xu, F.; Gu, W. Presence of segmented filamentous bacteria in human children and its potential role in the modulation of human gut immunity. Front. Microbiol. 2018, 9, 1403. [CrossRef]

61. Tan, T.G.; Sefik, E.; Geva-Zatorsky, N.; Kua, L.; Naskar, D.; Teng, F.; Pasman, L.; Ortiz-Lopez, A.; Jupp, R.; Wu, H.-J.J. Identifying species of symbiont bacteria from the human gut that, alone, can induce intestinal Th17 cells in mice. Proc. Natl. Acad. Sci. USA 2016, 113, E8141-E8150. [CrossRef]

62. Crotty, S. Follicular helper CD4 T cells (Tfh). Annu. Rev. Immunol. 2011, 29, 621-663. [CrossRef]

63. Perruzza, L.; Gargari, G.; Proietti, M.; Fosso, B.; D’Erchia, A.M.; Faliti, C.E.; Rezzonico-Jost, T.; Scribano, D.; Mauri, L.; Colombo, D. $\mathrm{T}$ follicular helper cells promote a beneficial gut ecosystem for host metabolic homeostasis by sensing microbiota-derived extracellular ATP. Cell Rep. 2017, 18, 2566-2575. [CrossRef]

64. Ansaldo, E.; Slayden, L.C.; Ching, K.L.; Koch, M.A.; Wolf, N.K.; Plichta, D.R.; Brown, E.M.; Graham, D.B.; Xavier, R.J.; Moon, J.J. Akkermansia muciniphila induces intestinal adaptive immune responses during homeostasis. Science 2019, 364, 1179-1184. [CrossRef] [PubMed]

65. Teng, F.; Klinger, C.N.; Felix, K.M.; Bradley, C.P.; Wu, E.; Tran, N.L.; Umesaki, Y.; Wu, H.-J.J. Gut microbiota drive autoimmune arthritis by promoting differentiation and migration of Peyer's patch T follicular helper cells. Immunity 2016, 44, 875-888. [CrossRef] [PubMed]

66. Parada Venegas, D.; De la Fuente, M.K.; Landskron, G.; González, M.J.; Quera, R.; Dijkstra, G.; Harmsen, H.J.; Faber, K.N.; Hermoso, M.A. Short chain fatty acids (SCFAs)-mediated gut epithelial and immune regulation and its relevance for inflammatory bowel diseases. Front. Immunol. 2019, 10, 277. [CrossRef]

67. Lavelle, A.; Sokol, H. Gut microbiota-derived metabolites as key actors in inflammatory bowel disease. Nat. Rev. Gastroenterol. Hepatol. 2020, 17, 223-237. [CrossRef]

68. Furusawa, Y.; Obata, Y.; Fukuda, S.; Endo, T.A.; Nakato, G.; Takahashi, D.; Nakanishi, Y.; Uetake, C.; Kato, K.; Kato, T. Commensal microbe-derived butyrate induces the differentiation of colonic regulatory T cells. Nature 2013, 504, 446-450. [CrossRef] [PubMed]

69. Smith, P.M.; Howitt, M.R.; Panikov, N.; Michaud, M.; Gallini, C.A.; Bohlooly-y, M.; Glickman, J.N.; Garrett, W.S. The microbial metabolites, short-chain fatty acids, regulate colonic Treg cell homeostasis. Science 2013, 341, 569-573. [CrossRef] [PubMed]

70. Haghikia, A.; Jörg, S.; Duscha, A.; Berg, J.; Manzel, A.; Waschbisch, A.; Hammer, A.; Lee, D.-H.; May, C.; Wilck, N. Dietary fatty acids directly impact central nervous system autoimmunity via the small intestine. Immunity 2015, 43, 817-829. [CrossRef]

71. Atarashi, K.; Nishimura, J.; Shima, T.; Umesaki, Y.; Yamamoto, M.; Onoue, M.; Yagita, H.; Ishii, N.; Evans, R.; Honda, K. ATP drives lamina propria TH 17 cell differentiation. Nature 2008, 455, 808-812. [CrossRef]

72. Hand, T.; Belkaid, Y.J. Microbial control of regulatory and effector T cell responses in the gut. Curr. Opin. Immunol. 2010, $22,63-72$. [CrossRef]

73. Mazmanian, S.K.; Liu, C.H.; Tzianabos, A.O.; Kasper, D.L. An immunomodulatory molecule of symbiotic bacteria directs maturation of the host immune system. Cell 2005, 122, 107-118. [CrossRef]

74. Mazmanian, S.K.; Round, J.L.; Kasper, D.L. A microbial symbiosis factor prevents intestinal inflammatory disease. Nature 2008, 453, 620-625. [CrossRef] [PubMed]

75. Round, J.L.; Mazmanian, S.K. Inducible Foxp3+ regulatory T-cell development by a commensal bacterium of the intestinal microbiota. Proc. Natl. Acad. Sci. USA 2010, 107, 12204-12209. [CrossRef] [PubMed]

76. Shen, Y.; Torchia, M.L.G.; Lawson, G.W.; Karp, C.L.; Ashwell, J.D.; Mazmanian, S.K. Outer membrane vesicles of a human commensal mediate immune regulation and disease protection. Cell Host Microbe 2012, 12, 509-520. [CrossRef] [PubMed]

77. Dasgupta, S.; Erturk-Hasdemir, D.; Ochoa-Reparaz, J.; Reinecker, H.-C.; Kasper, D.L. Plasmacytoid dendritic cells mediate anti-inflammatory responses to a gut commensal molecule via both innate and adaptive mechanisms. Cell Host Microbe 2014, 15, 413-423. [CrossRef] [PubMed]

78. Chu, H.; Khosravi, A.; Kusumawardhani, I.P.; Kwon, A.H.; Vasconcelos, A.C.; Cunha, L.D.; Mayer, A.E.; Shen, Y.; Wu, W.L.; Kambal, A. Gene-microbiota interactions contribute to the pathogenesis of inflammatory bowel disease. Science 2016, 352, 1116-1120. [CrossRef] 
79. Lee, C.; Verma, R.; Byun, S.; Jeun, E.-J.; Kim, G.-C.; Lee, S.; Kang, H.-J.; Kim, C.J.; Sharma, G.; Lahiri, A.; et al. Structural specificities of cell surface $\beta$-glucan polysaccharides determine commensal yeast mediated immuno-modulatory activities. Nat. Commun. 2021, 12, 1-16.

80. Mucida, D.; Pino-Lagos, K.; Kim, G.; Nowak, E.; Benson, M.J.; Kronenberg, M.; Noelle, R.J.; Cheroutre, H. Retinoic acid can directly promote TGF- $\beta$-mediated Foxp3+ Treg cell conversion of naive T cells. Immunity 2009, 30, 471. [CrossRef]

81. Yamaguchi, T.; Hirota, K.; Nagahama, K.; Ohkawa, K.; Takahashi, T.; Nomura, T.; Sakaguchi, S.J.I. Control of immune responses by antigen-specific regulatory $\mathrm{T}$ cells expressing the folate receptor. Immunity 2007, 27, 145-159. [CrossRef]

82. Kunisawa, J.; Hashimoto, E.; Ishikawa, I.; Kiyono, H. A pivotal role of vitamin B9 in the maintenance of regulatory T cells in vitro and in vivo. PLoS ONE 2012, 7, e32094. [CrossRef]

83. Singh, N.; Gurav, A.; Sivaprakasam, S.; Brady, E.; Padia, R.; Shi, H.; Thangaraju, M.; Prasad, P.D.; Manicassamy, S.; Munn, D.H Activation of Gpr109a, receptor for niacin and the commensal metabolite butyrate, suppresses colonic inflammation and carcinogenesis. Immunity 2014, 40, 128-139. [CrossRef]

84. Zeng, H.; Chi, H. Metabolic control of regulatory T cell development and function. Trends Immunol. 2015, 36, 3-12. [CrossRef]

85. Kuipers, F.; de Boer, J.F.; Staels, B. Microbiome modulation of the host adaptive immunity through bile acid modification. Cell Metab. 2020, 31, 445-447. [CrossRef] [PubMed]

86. Ridlon, J.M.; Harris, S.C.; Bhowmik, S.; Kang, D.-J.; Hylemon, P.B. Consequences of bile salt biotransformations by intestinal bacteria. Gut Microbes 2016, 7, 22-39. [CrossRef] [PubMed]

87. Ridlon, J.M.; Kang, D.-J.; Hylemon, P.B. Bile salt biotransformations by human intestinal bacteria. J. Lipid Res. 2006, 47, 241-259. [CrossRef] [PubMed]

88. Devkota, S.; Wang, Y.; Musch, M.W.; Leone, V.; Fehlner-Peach, H.; Nadimpalli, A.; Antonopoulos, D.A.; Jabri, B.; Chang, E.B. Dietary-fat-induced taurocholic acid promotes pathobiont expansion and colitis in Il10-/- mice. Nature 2012, 487, 104-108. [CrossRef]

89. Li, W.; Hang, S.; Fang, Y.; Bae, S.; Zhang, Y.; Zhang, M.; Wang, G.; McCurry, M.D.; Bae, M.; Paik, D. A bacterial bile acid metabolite modulates Treg activity through the nuclear hormone receptor NR4A1. Cell Host Microbe 2021, 29, 1366-1377.e1369. [CrossRef]

90. Xu, K.; Cai, H.; Shen, Y. Management of corona virus disease-19 (COVID-19): The Zhejiang experience. J. Zhejiang Univ. 2020, 49, 147-157.

91. Zuo, T.; Zhang, F.; Lui, G.C.; Yeoh, Y.K.; Li, A.Y.; Zhan, H.; Wan, Y.; Chung, A.C.; Cheung, C.P.; Chen, N. Alterations in gut microbiota of patients with COVID-19 during time of hospitalization. Gastroenterology 2020, 159, 944-955.e948. [CrossRef] [PubMed]

92. Gu, S.; Chen, Y.; Wu, Z.; Chen, Y.; Gao, H.; Lv, L.; Guo, F.; Zhang, X.; Luo, R.; Huang, C. Alterations of the gut microbiota in patients with coronavirus disease 2019 or H1N1 influenza. Clin. Infect. Dis. 2020, 71, 2669-2678. [CrossRef] [PubMed]

93. Yeoh, Y.K.; Zuo, T.; Lui, G.C.-Y.; Zhang, F.; Liu, Q.; Li, A.Y.; Chung, A.C.; Cheung, C.P.; Tso, E.Y.; Fung, K.S. Gut microbiota composition reflects disease severity and dysfunctional immune responses in patients with COVID-19. Gut 2021, 70,698-706. [CrossRef] [PubMed]

94. Tang, L.; Gu, S.; Gong, Y.; Li, B.; Lu, H.; Li, Q.; Zhang, R.; Gao, X.; Wu, Z.; Zhang, J. Clinical significance of the correlation between changes in the major intestinal bacteria species and COVID-19 severity. Engineering 2020, 6, 1178-1184. [CrossRef]

95. Prasad, R.; Patton, M.J.; Floyd, J.L.; Vieira, C.P.; Fortmann, S.D.; DuPont, M.; Harbour, A.; See, J.R.C.; Wright, J.; Lamendella, R. Plasma microbiome in COVID-19 subjects: An indicator of gut barrier defects and dysbiosis. bioRxiv 2021. [CrossRef]

96. Newsome, R.C.; Gauthier, J.; Hernandez, M.C.; Abraham, G.E.; Robinson, T.O.; Williams, H.B.; Sloan, M.; Owings, A.; Laird, H.; Christian, T. The gut microbiome of COVID-19 recovered patients returns to uninfected status in a minority-dominated United States cohort. Gut Microbes 2021, 13, 1-15. [CrossRef]

97. Lv, L.; Jiang, H.; Chen, Y.; Gu, S.; Xia, J.; Zhang, H.; Lu, Y.; Yan, R.; Li, L. The faecal metabolome in COVID-19 patients is altered and associated with clinical features and gut microbes. Anal. Chim. Acta 2021, 1152, 338267. [CrossRef]

98. Chen, Y.; Gu, S.; Chen, Y.; Lu, H.; Shi, D.; Guo, J.; Wu, W.-R.; Yang, Y.; Li, Y.; Xu, K.-J. Six-month follow-up of gut microbiota richness in patients with COVID-19. Gut 2022, 71, 222-225. [CrossRef] [PubMed]

99. Mazzarelli, A.; Giancola, M.L.; Farina, A.; Marchioni, L.; Rueca, M.; Gruber, C.E.M.; Bartolini, B.; Ascoli Bartoli, T.; Maffongelli, G.; Capobianchi, M.R. 16S rRNA gene sequencing of rectal swab in patients affected by COVID-19. PLoS ONE 2021, 16, e0247041. [CrossRef]

100. Lv, L.; Gu, S.; Jiang, H.; Yan, R.; Chen, Y.; Chen, Y.; Luo, R.; Huang, C.; Lu, H.; Zheng, B. Gut mycobiota alterations in patients with COVID-19 and H1N1 infections and their associations with clinical features. Commun. Biol. 2021, 4, 1-11. [CrossRef] [PubMed]

101. Yu, L.; Tong, Y.; Shen, G.; Fu, A.; Lai, Y.; Zhou, X.; Yuan, Y.; Wang, Y.; Pan, Y.; Yu, Z. Immunodepletion with hypoxemia: A potential high risk subtype of coronavirus disease 2019. MedRxiv 2020. [CrossRef]

102. Keely, S.; Talley, N.J.; Hansbro, P.M. Pulmonary-intestinal cross-talk in mucosal inflammatory disease. Mucosal Immunol. 2012, 5, 7-18. [CrossRef] [PubMed]

103. Dumas, A.; Bernard, L.; Poquet, Y.; Lugo-Villarino, G.; Neyrolles, O. The role of the lung microbiota and the gut-lung axis in respiratory infectious diseases. Cell. Microbiol. 2018, 20, e12966. [CrossRef]

104. Gauguet, S.; D’Ortona, S.; Ahnger-Pier, K.; Duan, B.; Surana, N.K.; Lu, R.; Cywes-Bentley, C.; Gadjeva, M.; Shan, Q.; Priebe, G.P.; et al. Intestinal microbiota of mice influences resistance to Staphylococcus aureus pneumonia. Infect. Immun. 2015, 83, 4003-4014. [CrossRef] 
105. Bruzzese, E.; Callegari, M.L.; Raia, V.; Viscovo, S.; Scotto, R.; Ferrari, S.; Morelli, L.; Buccigrossi, V.; Lo Vecchio, A.; Ruberto, E.; et al. Disrupted intestinal microbiota and intestinal inflammation in children with cystic fibrosis and its restoration with Lactobacillus GG: A randomised clinical trial. PLoS ONE 2014, 9, e87796. [CrossRef] [PubMed]

106. Ranucci, G.; Buccigrossi, V.; De Freitas, M.B.; Guarino, A.; Giannattasio, A. Early-life intestine microbiota and lung health in children. J. Immunol. Res. 2017, 2017, 1-5. [CrossRef] [PubMed]

107. Zhang, Q.; Hu, J.; Feng, J.-W.; Hu, X.-T.; Wang, T.; Gong, W.-X.; Huang, K.; Guo, Y.-X.; Zou, Z.; Lin, X.; et al. Influenza infection elicits an expansion of gut population of endogenous Bifidobacterium animalis which protects mice against infection. Genome Biol. 2020, 21, 1-26. [CrossRef]

108. Budden, K.F.; Gellatly, S.L.; Wood, D.L.; Cooper, M.A.; Morrison, M.; Hugenholtz, P.; Hansbro, P.M. Emerging pathogenic links between microbiota and the gut-lung axis. Nat. Rev. Microbiol. 2017, 15, 55-63. [CrossRef] [PubMed]

109. Sze, M.A.; Tsuruta, M.; Yang, S.-W.J.; Oh, Y.; Man, S.P.; Hogg, J.C.; Sin, D.D. Changes in the bacterial microbiota in gut, blood, and lungs following acute LPS instillation into mice lungs. PLoS ONE 2014, 9, e111228. [CrossRef] [PubMed]

110. Tirone, C.; Pezza, L.; Paladini, A.; Tana, M.; Aurilia, C.; Lio, A.; D’Ippolito, S.; Tersigni, C.; Posteraro, B.; Sanguinetti, M.; et al. Gut and lung microbiota in preterm infants: Immunological modulation and implication in neonatal outcomes. Front. Immunol. 2019, 10, 2910. [CrossRef]

111. Zhou, D.; Wang, Q.; Liu, H. Coronavirus disease 2019 and the gut-lung axis. Int. J. Infect. Dis. 2021, 113, 300-307. [CrossRef]

112. Candela, M.; Biagi, E.; Soverini, M.; Consolandi, C.; Quercia, S.; Severgnini, M.; Peano, C.; Turroni, S.; Rampelli, S.; Pozzilli, P.; et al. Modulation of gut microbiota dysbioses in type 2 diabetic patients by macrobiotic Ma-Pi 2 diet. Br. J. Nutr. 2016, 116, 80-93. [CrossRef]

113. Sedighi, M.; Razavi, S.; Navab-Moghadam, F.; Khamseh, M.E.; Alaei-Shahmiri, F.; Mehrtash, A.; Amirmozafari, N. Comparison of gut microbiota in adult patients with type 2 diabetes and healthy individuals. Microb. Pathog. 2017, 111, 362-369. [CrossRef]

114. Wu, X.; Ma, C.; Han, L.; Nawaz, M.; Gao, F.; Zhang, X.; Yu, P.; Zhao, C.; Li, L.; Zhou, A.; et al. Molecular characterisation of the faecal microbiota in patients with type II diabetes. Curr. Microbiol. 2010, 61, 69-78. [CrossRef] [PubMed]

115. Larsen, N.; Vogensen, F.K.; Van Den Berg, F.W.; Nielsen, D.S.; Andreasen, A.S.; Pedersen, B.K.; Al-Soud, W.A.; Sørensen, S.J.; Hansen, L.H.; Jakobsen, M. Gut microbiota in human adults with type 2 diabetes differs from non-diabetic adults. PLoS ONE 2010, 5, e9085. [CrossRef] [PubMed]

116. Gao, R.; Zhu, C.; Li, H.; Yin, M.; Pan, C.; Huang, L.; Kong, C.; Wang, X.; Zhang, Y.; Qu, S. Dysbiosis signatures of gut microbiota along the sequence from healthy, young patients to those with overweight and obesity. Obesity 2018, 26, 351-361. [CrossRef]

117. Wu, H.; Esteve, E.; Tremaroli, V.; Khan, M.T.; Caesar, R.; Mannerås-Holm, L.; Ståhlman, M.; Olsson, L.M.; Serino, M.; Planas-Fèlix, M. Metformin alters the gut microbiome of individuals with treatment-naive type 2 diabetes, contributing to the therapeutic effects of the drug. Nat. Med. 2017, 23, 850-858. [CrossRef]

118. Le, T.K.C.; Hosaka, T.; Nguyen, T.T.; Kassu, A.; Dang, T.O.; Tran, H.B.; Pham, T.P.; Tran, Q.B.; Le, T.H.H.; Da Pham, X. Bifidobacterium species lower serum glucose, increase expressions of insulin signaling proteins, and improve adipokine profile in diabetic mice. Biomed. Res. 2015, 36, 63-70. [CrossRef]

119. Moya-Pérez, A.; Neef, A.; Sanz, Y. Bifidobacterium pseudocatenulatum CECT 7765 reduces obesity-associated inflammation by restoring the lymphocyte-macrophage balance and gut microbiota structure in high-fat diet-fed mice. PLoS ONE 2015, 10, e0126976. [CrossRef] [PubMed]

120. Kikuchi, K.; Othman, M.B.; Sakamoto, K. Sterilized bifidobacteria suppressed fat accumulation and blood glucose level. Biochem. Biophys. Res. Commun. 2018, 501, 1041-1047. [CrossRef]

121. Aoki, R.; Kamikado, K.; Suda, W.; Takii, H.; Mikami, Y.; Suganuma, N.; Hattori, M.; Koga, Y. A proliferative probiotic Bifidobacterium strain in the gut ameliorates progression of metabolic disorders via microbiota modulation and acetate elevation. Sci. Rep. 2017, 7, 1-10. [CrossRef]

122. Yang, J.; Lee, Y.; Kim, Y.; Lee, S.; Ryu, S.; Fukuda, S.; Hase, K.; Yang, C.; Lim, H.; Kim, M. Gut commensal Bacteroides acidifaciens prevents obesity and improves insulin sensitivity in mice. Mucosal Immunol. 2017, 10, 104-116. [CrossRef]

123. Gauffin Cano, P.; Santacruz, A.; Moya, Á.; Sanz, Y. Bacteroides uniformis CECT 7771 ameliorates metabolic and immunological dysfunction in mice with high-fat-diet induced obesity. PLoS ONE 2012, 7, e41079. [CrossRef]

124. Zhang, X.; Shen, D.; Fang, Z.; Jie, Z.; Qiu, X.; Zhang, C.; Chen, Y.; Ji, L. Human gut microbiota changes reveal the progression of glucose intolerance. PLoS ONE 2013, 8, e71108. [CrossRef] [PubMed]

125. Greer, R.L.; Dong, X.; Moraes, A.C.F.; Zielke, R.A.; Fernandes, G.R.; Peremyslova, E.; Vasquez-Perez, S.; Schoenborn, A.A.; Gomes, E.P.; Pereira, A.C. Akkermansia muciniphila mediates negative effects of IFN $\gamma$ on glucose metabolism. Nat. Commun. 2016, 7, 1-13. [CrossRef]

126. Eckburg, P.B.; Bik, E.M.; Bernstein, C.N.; Purdom, E.; Dethlefsen, L.; Sargent, M.; Gill, S.R.; Nelson, K.E.; Relman, D.A. Diversity of the human intestinal microbial flora. Science 2005, 308, 1635-1638. [CrossRef] [PubMed]

127. Lê, K.-A.; Li, Y.; Xu, X.; Liu, T.; Yang, W.; He, F.; Su, K.; Cai, D.H.; Go, V.L.W.; Pandol, S. Alterations in fecal Lactobacillus and Bifidobacterium species in type 2 diabetic patients in Southern China population. Front. Physiol. 2013, 3, 496. [CrossRef] [PubMed]

128. Kasubuchi, M.; Hasegawa, S.; Hiramatsu, T.; Ichimura, A.; Kimura, I. Dietary gut microbial metabolites, short-chain fatty acids, and host metabolic regulation. Nutrients 2015, 7, 2839-2849. [CrossRef] 
129. Perry, R.J.; Peng, L.; Barry, N.A.; Cline, G.W.; Zhang, D.; Cardone, R.L.; Petersen, K.F.; Kibbey, R.G.; Goodman, A.L.; Shulman, G.I. Acetate mediates a microbiome-brain- $\beta$-cell axis to promote metabolic syndrome. Nature 2016, 534, 213-217. [CrossRef]

130. Hiel, S.; Gianfrancesco, M.A.; Rodriguez, J.; Portheault, D.; Leyrolle, Q.; Bindels, L.B.; da Silveira Cauduro, C.G.; Mulders, M.D.; Zamariola, G.; Azzi, A.-S. Link between gut microbiota and health outcomes in inulin-treated obese patients: Lessons from the Food4Gut multicenter randomized placebo-controlled trial. Clin. Nutr. 2020, 39, 3618-3628. [CrossRef]

131. Ejtahed, H.-S.; Tito, R.Y.; Siadat, S.-D.; Hasani-Ranjbar, S.; Hoseini-Tavassol, Z.; Rymenans, L.; Verbeke, K.; Soroush, A.-R.; Raes, J.; Larijani, B. Metformin induces weight loss associated with gut microbiota alteration in non-diabetic obese women: A randomized double-blind clinical trial. Eur. J. Endocrinol. 2019, 180, 165-176. [CrossRef]

132. Forslund, K.; Hildebrand, F.; Nielsen, T.; Falony, G.; Le Chatelier, E.; Sunagawa, S.; Prifti, E.; Vieira-Silva, S.; Gudmundsdottir, V.; Pedersen, H.K. Disentangling type 2 diabetes and metformin treatment signatures in the human gut microbiota. Nature 2015, 528, 262-266. [CrossRef]

133. De La Cuesta-Zuluaga, J.; Mueller, N.T.; Corrales-Agudelo, V.; Velásquez-Mejía, E.P.; Carmona, J.A.; Abad, J.M.; Escobar, J.S Metformin is associated with higher relative abundance of mucin-degrading Akkermansia muciniphila and several short-chain fatty acid-producing microbiota in the gut. Diabetes Care 2017, 40, 54-62. [CrossRef]

134. Sun, L.; Xie, C.; Wang, G.; Wu, Y.; Wu, Q.; Wang, X.; Liu, J.; Deng, Y.; Xia, J.; Chen, B. Gut microbiota and intestinal FXR mediate the clinical benefits of metformin. Nat. Med. 2018, 24, 1919-1929. [CrossRef] [PubMed]

135. Huang, F.; Nilholm, C.; Roth, B.; Linninge, C.; Höglund, P.; Nyman, M.; Ohlsson, B. Anthropometric and metabolic improvements in human type 2 diabetes after introduction of an Okinawan-based Nordic diet are not associated with changes in microbial diversity or SCFA concentrations. Int. J. Food Sci. Nutr. 2018, 69, 729-740. [CrossRef]

136. Barengolts, E.; Green, S.J.; Eisenberg, Y.; Akbar, A.; Reddivari, B.; Layden, B.T.; Dugas, L.; Chlipala, G. Gut microbiota varies by opioid use, circulating leptin and oxytocin in African American men with diabetes and high burden of chronic disease. PLoS ONE 2018, 13, e0194171. [CrossRef]

137. Zhang, F.; Wang, M.; Yang, J.; Xu, Q.; Liang, C.; Chen, B.; Zhang, J.; Yang, Y.; Wang, H.; Shang, Y. Response of gut microbiota in type 2 diabetes to hypoglycemic agents. Endocrine 2019, 66, 485-493. [CrossRef] [PubMed]

138. Chávez-Carbajal, A.; Pizano-Zárate, M.L.; Hernández-Quiroz, F.; Ortiz-Luna, G.F.; Morales-Hernández, R.M.; Sales-Millán, D.; Hernández-Trejo, M.; García-Vite, A.; Beltrán-Lagunes, L.; Hoyo-Vadillo, C. Characterization of the gut microbiota of individuals at different T2D stages reveals a complex relationship with the host. Microorganisms 2020, 8, 94. [CrossRef]

139. Elbere, I.; Kalnina, I.; Silamikelis, I.; Konrade, I.; Zaharenko, L.; Sekace, K.; Radovica-Spalvina, I.; Fridmanis, D.; Gudra, D.; Pirags, V. Association of metformin administration with gut microbiome dysbiosis in healthy volunteers. PLOS ONE 2018, 13, e0204317. [CrossRef] [PubMed]

140. Lee, H.; Ko, G. Effect of metformin on metabolic improvement and gut microbiota. Appl. Environ. Microbiol. 2014, 80, 5935-5943. [CrossRef] [PubMed]

141. Cani, P.D.; de Vos, W.M. Next-generation beneficial microbes: The case of Akkermansia muciniphila. Front. Microbiol. 2017, 8, 1765. [CrossRef]

142. Delzenne, N.M.; Cani, P.D.; Everard, A.; Neyrinck, A.M.; Bindels, L.B. Gut microorganisms as promising targets for the management of type 2 diabetes. Diabetologia 2015, 58, 2206-2217. [CrossRef]

143. Kamyshnyi, O.; Matskevych, V.; Lenchuk, T.; Strilbytska, O.; Storey, K.; Lushchak, O. Metformin to decrease COVID-19 severity and mortality: Molecular mechanisms and therapeutic potential. Biomed. Pharmacother. 2021, 144, 112230. [CrossRef]

144. Putilin, D.A.; Evchenko, S.Y.; Fedoniuk, L.Y.; Tokarskyy, O.S.; Kamyshny, O.M.; Migenko, L.M.; Andreychyn, S.M.; Hanberher, I.I.; Bezruk, T.O. The influence of metformin to the transcriptional activity of the mTOR and FOX3 genes in parapancreatic adipose tissue of streptozotocin-induced diabetic rats. J. Med. Life 2020, 13, 50.

145. Bryrup, T.; Thomsen, C.W.; Kern, T.; Allin, K.H.; Brandslund, I.; Jørgensen, N.R.; Vestergaard, H.; Hansen, T.; Hansen, T.H.; Pedersen, O. Metformin-induced changes of the gut microbiota in healthy young men: Results of a non-blinded, one-armed intervention study. Diabetologia 2019, 62, 1024-1035. [CrossRef] [PubMed]

146. Shin, N.-R.; Lee, J.-C.; Lee, H.-Y.; Kim, M.-S.; Whon, T.W.; Lee, M.-S.; Bae, J.-W. An increase in the Akkermansia spp. population induced by metformin treatment improves glucose homeostasis in diet-induced obese mice. Gut 2014, 63, 727-735. [CrossRef] [PubMed]

147. Zhou, Z.-Y.; Ren, L.-W.; Zhan, P.; Yang, H.-Y.; Chai, D.-D.; Yu, Z.-W. Metformin exerts glucose-lowering action in high-fat fed mice via attenuating endotoxemia and enhancing insulin signaling. Acta Pharmacol. Sin. 2016, 37, 1063-1075. [CrossRef] [PubMed]

148. Zhang, Q.; Hu, N. Effects of metformin on the gut microbiota in obesity and type 2 diabetes mellitus. Diabetes Metab. Syndr. Obes. Targets Ther. 2020, 13, 5003. [CrossRef] [PubMed]

149. Bornstein, S.; Moschetta, M.; Kawano, Y.; Sacco, A.; Huynh, D.; Brooks, D.; Manier, S.; Fairfield, H.; Falank, C.; Roccaro, A.M. Metformin affects cortical bone mass and marrow adiposity in diet-induced obesity in male mice. Endocrinology 2017, 158, 3369-3385. [CrossRef]

150. Lee, H.; Lee, Y.; Kim, J.; An, J.; Lee, S.; Kong, H.; Song, Y.; Lee, C.-K.; Kim, K. Modulation of the gut microbiota by metformin improves metabolic profiles in aged obese mice. Gut Microbes 2018, 9, 155-165. [CrossRef]

151. Maida, A.; Lamont, B.; Cao, X.; Drucker, D.J. Metformin regulates the incretin receptor axis via a pathway dependent on peroxisome proliferator-activated receptor- $\alpha$ in mice. Diabetologia 2011, 54, 339-349. [CrossRef] 
152. Mannucci, E.; Ognibene, A.; Cremasco, F.; Bardini, G.; Mencucci, A.; Pierazzuoli, E.; Ciani, S.; Messeri, G.; Rotella, C.M. Effect of metformin on glucagon-like peptide 1 (GLP-1) and leptin levels in obese nondiabetic subjects. Diabetes Care 2001, 24, 489-494. [CrossRef]

153. Carter, D.; Howlett, H.C.S.; Wiernsperger, N.F.; Bailey, C.J. Differential effects of metformin on bile salt absorption from the jejunum and ileum. Diabetes Obes. Metab. 2003, 5, 120-125. [CrossRef]

154. Barengolts, E.; Smith, E.D. Considerations for gut microbiota and probiotics in patients with diabetes amidst the COVID-19 pandemic: A narrative review. Endocr. Pract. 2020, 26, 1186-1195. [CrossRef]

155. Enaud, R.; Prevel, R.; Ciarlo, E.; Beaufils, F.; Wieërs, G.; Guery, B.; Delhaes, L. The gut-lung axis in health and respiratory diseases: A place for inter-organ and inter-kingdom crosstalks. Front. Cell. Infect. Microbiol. 2020, 10, 9. [CrossRef]

156. Anand, S.; Mande, S.S. Diet, microbiota and gut-lung connection. Front. Microbiol. 2018, 9, 2147. [CrossRef]

157. Gozzi-Silva, S.C.; Teixeira, F.M.E.; Duarte, A.J.D.S.; Sato, M.N.; Oliveira, L.D.M. Immunomodulatory Role of Nutrients: How Can Pulmonary Dysfunctions Improve? Front. Nutr. 2021, 8, 674258. [CrossRef] [PubMed]

158. Kimball, A.; Hatfield, K.M.; Arons, M.; James, A.; Taylor, J.; Spicer, K.; Bardossy, A.C.; Oakley, L.P.; Tanwar, S.; Chisty, Z. Preliminary Estimates of the Prevalence of Selected Underlying Health Conditions among Patients with Coronavirus Disease 2019-United States, February 12-March 28, 2020; Centers for Disease Control and Prevention: Atlanta, GA, USA, 2020.

159. Wu, Z.; McGoogan, J.M. Characteristics of and important lessons from the coronavirus disease 2019 (COVID-19) outbreak in China: Summary of a report of 72314 cases from the Chinese Center for Disease Control and Prevention. JAMA 2020, 323, 1239-1242. [CrossRef] [PubMed]

160. Zhou, W.; Ye, S.; Wang, W.; Li, S.; Hu, Q.J. Clinical features of COVID-19 patients with diabetes and secondary hyperglycemia. J. Diabetes Res. 2020, 2020, 1-9. [CrossRef]

161. Figueroa-Pizano, M.D.; Campa-Mada, A.C.; Carvajal-Millan, E.; Martinez-Robinson, K.G.; Chu, A.R. The underlying mechanisms for severe COVID-19 progression in people with diabetes mellitus: A critical review. AIMS Public Health 2021, 8, 720. [CrossRef] [PubMed]

162. Stentz, F.B.; Kitabchi, A.E. Activated T lymphocytes in type 2 diabetes: Implications from in vitro studies. Curr. Drug Targets 2003, 4, 493-503. [CrossRef]

163. Jagannathan-Bogdan, M.; McDonnell, M.E.; Shin, H.; Rehman, Q.; Hasturk, H.; Apovian, C.M.; Nikolajczyk, B.S. Elevated proinflammatory cytokine production by a skewed $\mathrm{T}$ cell compartment requires monocytes and promotes inflammation in type 2 diabetes. J. Immunol. 2011, 186, 1162-1172. [CrossRef]

164. Yuan, N.; Zhang, H.-F.; Wei, Q.; Wang, P.; Guo, W.-Y. Expression of CD4+ CD25+ Foxp3+ regulatory T cells, interleukin 10 and transforming growth factor $\beta$ in newly diagnosed type 2 diabetic patients. Exp. Clin. Endocrinol. Diabetes 2018, 126, 96-101. [CrossRef]

165. Zhou, T.; Hu, Z.; Yang, S.; Sun, L.; Yu, Z.; Wang, G. Role of adaptive and innate immunity in type 2 diabetes mellitus. J. Diabetes Res. 2018, 2018, 7457269. [CrossRef]

166. Zeng, L.; Lu, H.; Deng, H.; Mu, P.; Li, X.; Wang, M. Noninferiority effects on glycemic control and $\beta$-cell function improvement in newly diagnosed type 2 diabetes patients: Basal insulin monotherapy versus continuous subcutaneous insulin infusion treatment. Diabetes Technol. Ther. 2012, 14, 35-42. [CrossRef] [PubMed]

167. Wang, M.; Chen, F.; Wang, J.; Zeng, Z.; Yang, Q.; Shao, S. Th17 and Treg lymphocytes in obesity and Type 2 diabetic patients. Clin. Immunol. 2018, 197, 77-85. [CrossRef] [PubMed]

168. Li, Q.; Gao, Z.; Wang, H.; Wu, H.; Liu, Y.; Yang, Y.; Han, L.; Wang, X.; Zhao, L.; Tong, X. Intestinal immunomodulatory cells (T lymphocytes): A bridge between gut microbiota and diabetes. Mediat. Inflamm. 2018, 2018, 9830939. [CrossRef]

169. Qin, J.; Li, Y.; Cai, Z.; Li, S.; Zhu, J.; Zhang, F.; Liang, S.; Zhang, W.; Guan, Y.; Shen, D. A metagenome-wide association study of gut microbiota in type 2 diabetes. Nature 2012, 490, 55-60. [CrossRef]

170. Karlsson, F.H.; Tremaroli, V.; Nookaew, I.; Bergström, G.; Behre, C.J.; Fagerberg, B.; Nielsen, J.; Bäckhed, F. Gut metagenome in European women with normal, impaired and diabetic glucose control. Nature 2013, 498, 99-103. [CrossRef] [PubMed]

171. Pedersen, H.K.; Gudmundsdottir, V.; Nielsen, H.B.; Hyotylainen, T.; Nielsen, T.; Jensen, B.A.; Forslund, K.; Hildebrand, F.; Prifti, E.; Falony, G. Human gut microbes impact host serum metabolome and insulin sensitivity. Nature 2016, 535, 376-381. [CrossRef]

172. Wu, H.; Tremaroli, V.; Schmidt, C.; Lundqvist, A.; Olsson, L.M.; Krämer, M.; Gummesson, A.; Perkins, R.; Bergström, G.; Bäckhed, F. The gut microbiota in prediabetes and diabetes: A population-based cross-sectional study. Cell Metab. 2020, 32, 379-390.e373. [CrossRef]

173. Sato, J.; Kanazawa, A.; Ikeda, F.; Yoshihara, T.; Goto, H.; Abe, H.; Komiya, K.; Kawaguchi, M.; Shimizu, T.; Ogihara, T. Gut dysbiosis and detection of "live gut bacteria" in blood of Japanese patients with type 2 diabetes. Diabetes Care 2014, 37, 2343-2350. [CrossRef] [PubMed]

174. Huda, M.N.; Kim, M.; Bennett, B.J. Modulating the Microbiota as a Therapeutic Intervention for Type 2 Diabetes. Front. Endocrinol. 2021, 12, 153. [CrossRef] [PubMed]

175. Asarat, M.; Apostolopoulos, V.; Vasiljevic, T.; Donkor, O. Short-chain fatty acids regulate cytokines and Th17/Treg cells in human peripheral blood mononuclear cells in vitro. Immunol. Investig. 2016, 45, 205-222. [CrossRef] [PubMed]

176. Sharma, S.; Ray, A.; Sadasivam, B. Metformin in COVID-19: A possible role beyond diabetes. Diabetes Res. Clin. Pract. 2020, 164, 108183. [CrossRef] [PubMed] 